\title{
Contribution to the validity and taxonomic status of the European fossil shrew Sorex subaraneus and the origin of Sorex araneus (Soricidae, Eulipotyphla, Insectivora, Mammalia)
}

\author{
Barbara Rzebik-Kowalska and Andrea Pereswiet-Soltan
}

\begin{abstract}
The taxonomy of many fossil shrews in Europe is still unclear. The aim of the study was to establish the validity and the taxonomic status of the European fossil shrew, Sorex subaraneus, often compared with or identified as other fossil and recent species: Sorex runtonensis, Sorex tundrensis, Sorex satunini and Sorex araneus. Middle Pleistocene material of $S$. subaraneus from the type locality of Erpfingen (Germany) was redescribed, and it was compared with specimens of the same species found in Polish localities, with fossil specimens of S. runtonensis, fossil and recent $S$. araneus (all from Poland) as well as with fossil and recent Sorex tundrensis and Sorex satunini from Russia. The morphological characters, measurements and statistical analysis showed that $S$. subaraneus and $S$. runtonensis are valid species. Sorex subaraneus differs from the smaller $S$. runtonensis and $S$. tundrensis, similar in size $S$. satunini as well as from the larger $S$. araneus. A comparison of dimensions of several fossil and recent $S$. araneus populations from different localities demonstrated that it has not changed over geological time and that $S$. subaraneus differed in the same degree from its oldest late Middle Pleistocene, Late Pleistocene, Holocene and recent specimens living in the same area. The paleontological data show that $S$. runtonensis, $S$. subaraneus and $S$. araneus inhabited Europe at the same time. If the identification of the European remains of $S$. subaraneus and $S$. araneus is correct, then the ancestry of $S$. araneus from $S$. subaraneus is rather doubtful.
\end{abstract}

Barbara Rzebik-Kowalska, Institute of Systematics and Evolution of Animals, Polish Academy of Science, Sławkowska 17, 31-016 Kraków, Poland. rzebik@isez.pan.krakow.pl

Andrea Pereswiet-Soltan, Wroclaw University, Department of Paleozoology, Sienkiewicza 21, 50-335

Wrocław, Poland and Club Speleologico Proteo Vicenza, Viale Riviera Berica 631, 36-100 Vicenza, Italy pereswiet_soltan@yahoo.it

Keywords: Insectivore mammals; Europe; Pleistocene; species validity; ancestry

Submission: 26 June 2-17 Acceptance: 29 June 2018

Rzebik-Kowalska, Barbara and Pereswiet-Soltan, Andrea. 2018. Contribution to the validity and taxonomic status of the European fossil shrew Sorex subaraneus and the origin of Sorex araneus (Soricidae, Eulipotyphla, Insectivora, Mammalia). Palaeontologia Electronica 21.2.33A 1-29. https://doi.org/10.26879/788

palaeo-electronica.org/content/2018/2261-validity-of-sorex-subaraneus

Copyright: August 2018 Palaeontological Association.

This is an open access article distributed under the terms of Attribution-NonCommercial-ShareAlike 4.0 International (CC BY-NC-SA 4.0), which permits users to copy and redistribute the material in any medium or format, provided it is not used for commercial purposes and the original author and source are credited, with indications if any changes are made.

creativecommons.org/licenses/by-nc-sa/4.0/ 


\section{INTRODUCTION}

The origin of species, especially the recent ones, the temporal aspects of their appearances as well as the geographical source of populations always arouses interest. One interesting species of unexplained origin and age is the common redtoothed shrew, Sorex araneus Linnaeus, 1758, which lives nowadays in Europe. The origin of the genus Sorex is not precisely known. Its oldest fossil remains (mentioned as Sorex sp.) come from the Late Miocene (MN11-MN12) localities in China and western Siberia (Storch et al., 1998, Qiu and Storch, 2005).

So far 74 contemporary species of this genus have been described from Europe, Asia and North America (Lapini and Testone, 1998; Wolsan and Hutterer, 1998; Brünner et al., 2002). Twelve of them, among others Sorex araneus, inhabit Europe. Today, $S$. araneus occupies a large territory including almost all Europe and continental Asia north of steppe zone (Yudin, 1989). Different populations in this vast area show enormous karyotype variability. On the basis of this variability several dozen chromosomal races have been described within $S$. araneus. Some of them were later recognized as different species (Hausser et al., 1985; Searle and Wójcik, 1998).

According to paleontological data, the oldest remains of $S$. araneus come from the Early Pleistocene European localities, although S. cf. araneus was identified earlier, from the Late Pliocene (MN16) of Germany (Rzebik-Kowalska, 1998). On the other hand, the only reference to this form in Asia (named Sorex "araneus") was found in the Late Pleistocene of China (Zhang et al., 1993). However, Storch et al. (1998) considered its specific identification questionable.

It is generally suggested that fossil European Sorex subaraneus described by Heller (1958) from the Middle Pleistocene locality Erpfingen (Germany) was the ancestral form of $S$. araneus. According to Jammot (1977), it was the ancestor of the recent $S$. araneus and of $S$. coronatus Millet, 1828 living today in Western Europe. On the other hand, Zaitsev and Baryshnikov (2002) tried to prove that $S$. subaraneus does not differ much in size and morphology from the Caucasian recent and Middle Pleistocene Sorex satunini Ognev, 1922. According to them, both forms are probably conspecific and their names should be synonymized. In this case, the name "satunini" would have priority over the name "subaraneus". If this idea was true, then the ancestor of $S$. araneus would have been of Asian origins.
On the other hand, Rofes et al. (2016) thought that two fossil taxa, S. subaraneus and S. runtonensis Hinton, 1911, described from the Early Pleistocene of West Runton (England) could be regarded as "a morphological continuum of the same species" and the name "runtonensis" would have priority. This study also questioned the validity of $S$. subaraneus species and in consequence its probability as the ancestor of $S$. araneus. Because Osipova et al. (2006) have shown that the morphology and size of the fossil European S. runtonensis are similar to the morphology and size of the Eastern Palearctic S. tundrensis Merriam, 1900 , the latter species should also be considered in the discussion on the validity of $S$. subaraneus.

The present paper attempts to examine the discussion described above comparing the size and morphology of $S$. araneus, $S$. runtonensis, $S$. tundrensis and $S$. satununi with the type material of $S$. subaraneus from Erpfingen and from Polish localities in order to either support or falsify its validity and the putative ancestry of the recent Sorex araneus. This can help to find out when and where the composition of recent insectivore mammal fauna of Poland and whole Europe was formed.

To do so, the first detailed description (in the paleontological sense) of the fossil and recent Sorex araneus mandible and upper and lower dentition, as well as a redescription of the type specimens of $S$. subaraneus from Erpfingen were made. As the upper jaws are generally rare in the fossil material and more fragmentary, we based our measurements, morphological observation and statistical analysis mainly on the lower jaws and lower dentitions. Our experience shows that teeth are good proxies of the size in shrews. Research by Moncunill-Solé et al. (2016) seems to confirm this presumption.

\section{MATERIAL AND METHODS}

The material (Appendix 1) includes the typical population of Sorex subaraneus from Erpfingen (Germany), specimens of S. subaraneus, S. runtonensis and fossil and recent $S$. araneus (all collected from Poland) as comparative material. Measurements of specimens and their morphological characters were taken according to Reumer (1984) and Zaitsev and Baryshnikov (2002). Some Soricidae teeth (I1, i1, a1) were measured along their buccal sides, all other teeth (P4-M3 and p4m3) on their occlusal surfaces.

The statistical analyses were conducted in two stages. We used Principal Component Analy- 
sis (PCA) to check whether the studied material (originating from different localities and geological times) is composed of distinct morphological groups. Analysis of Variance (ANOVA) with $\alpha<0.05$, together with the post-hoc Tukeys' pairwise test, was conducted to examine the statistical significance of differences between groups discerned in the PCA diagrams. All calculations were performed with the program PAST v3. 12 (Hammer et al., 2001).

We examined fragments of mandibles of fossil Sorex subaraneus from the type locality (Erpfingen) as well as fossil S. subaraneus, S. runtonensis and fossil and recent $S$. araneus (all from Poland). Different analyses were conducted combining the various measurements. The two most representative encompassed tooth measurements ( $L$ and $W$ of $m 1, m 2, m 3$ and $L$ of $m 1-m 3$ ), and mandible dimensions ( $L$ of $m 1-m 3$ alveoli, $H$ of ascending ramus and $\mathrm{W}$ of coronoid process).

The specimens described are housed in the collections of the GeoZentrum Nordbayern of the Erlangen-Nürnberg University (Germany) and in the Institute of Systematics and Evolution of Animals Polish Academy of Sciences in Kraków and in the Institute of Paleobiology of the Polish Academy of Sciences in Warsow (Poland).

\section{Abbreviations}

$\mathrm{N}=$ number of specimens, $\mathrm{L}=$ maximum length, $\mathrm{W}$ $=$ maximum width, $\mathrm{H}=$ maximum height, $\mathrm{sd}=$ standard deviation, $\mathrm{cv}=$ coefficient of variation, $S . a(R)$ = Sorex araneus (recent), S.a $(\mathrm{f})=$ Sorex araneus (fossil), S.s $(G)$ = Sorex subaraneus (Germany), S.s $(\mathrm{P})=$ Sorex subaraneus $($ Poland $)$, S.r $(\mathrm{P})=$ Sorex runtonensis (Poland), nos. coll. Heller = number of Heller's collection (The GeoZentrum Nordbayern of the Erlangen-Nürnberg University, Germany), $\mathrm{M}=$ mammal collection, $\mathrm{MF}=$ fossil mammal collection (The Institute of Sysytematics and Evolution of Animals, Polish Academy of Sciences, Kraków), ZPAL M = fossil mammal collection (Institute of Paleobiology of the PolishAcademy of Sciences, Warsaw).

\section{SYSTEMATIC PALAEONTOLOGY}

Class MAMMALIA Linnaeus, 1758

Superorder INSECTIVORA sensu Novacek, 1986

Order EULIPOTYPHLA Waddell, Okada and Hasegawa, 1999

Family SORICIDAE Fischer, 1814 Genus SOREX Linnaeus, 1758

Type Species. Sorex araneus Linnaeus, 1758
Sorex subaraneus Heller, 1958 (type population)

Figures 1.7-8, 2.5-6, 3, 4, 5, 6

The type material of Sorex subaraneus from Erpfingen (Appendix 1) is devoid of upper dentition and, with the exception of the holotype, consists of 28 fragments of mandibles. Most of them are toothless, but some contain different types of teeth. In general, all types of lower teeth (with the exception of i1), as well as coronoid and condyloid processes, can be found in the material.

Unfortunately, the holotype of Sorex subaraneus designated by Heller (1958) has been lost. It represented the left mandible with i1-m2 and coronoid and condyloid processes. In a single sentence diagnosis Heller (1958) only wrote that the size of the form described as a new species" is close to the size of $S$. araneus, however it is slightly smaller". According to him, the size of the Erpfingen specimens exceeds the size of other Quaternary species inhabiting Central Europe such as Sorex aranoides Heller,1930, (now a synonym of S. runtonensis; van der Meulen, 1973; Jammot, 1977), S. runtonensis and S. praealpinus Heller, 1930. On the other hand, it approaches in dimensions the Plio/Pleistocene S. praearaneus Kormos, 1934 [now Sorex (Drepanosorex) praearaneus; Reumer, 1984] from Villány (Hungary), although it is different in morphology (e.g., its mental foramen is situated below the trigonid of $\mathrm{m} 1$ and in $S$. praearaneus below the p4).

To study the typical material, we used photos and measurements of the $S$. subaraneus specimens from Erpfingen send to us by Dr Lutz Maul. The photos were taken in buccal, lingual, occlusal and posterior views. This new data extended our knowledge of $S$. subaraneus size and its morphology in comparison with Heller's description and allowed a comparison with specimens of $S$. subaraneus, $S$. runtonensis and $S$. araneus found in Poland.

Description of the holotype. In his paper of 1958 , Heller wrote that the description was based in principle on the best-preserved specimen, the left mandible with $\mathrm{i} 1-\mathrm{m} 2$. According to Heller its i1 is tricuspulate, the a1 single-cusped and p4 twocusped. The $\mathrm{m} 3$ is unreduced. The coronoid process is vertical and slim, and its apex bends slightly towards the posterior side. The coronoid spicule is well developed. The upper sigmoid notch forms a right angle. The interarticular area of the condyloid process reaches almost the end of the lower facet. The mental foramen is situated below the protoconid of $\mathrm{m} 1$. In summary, Heller only stated that the morphology of the remaining speci- 


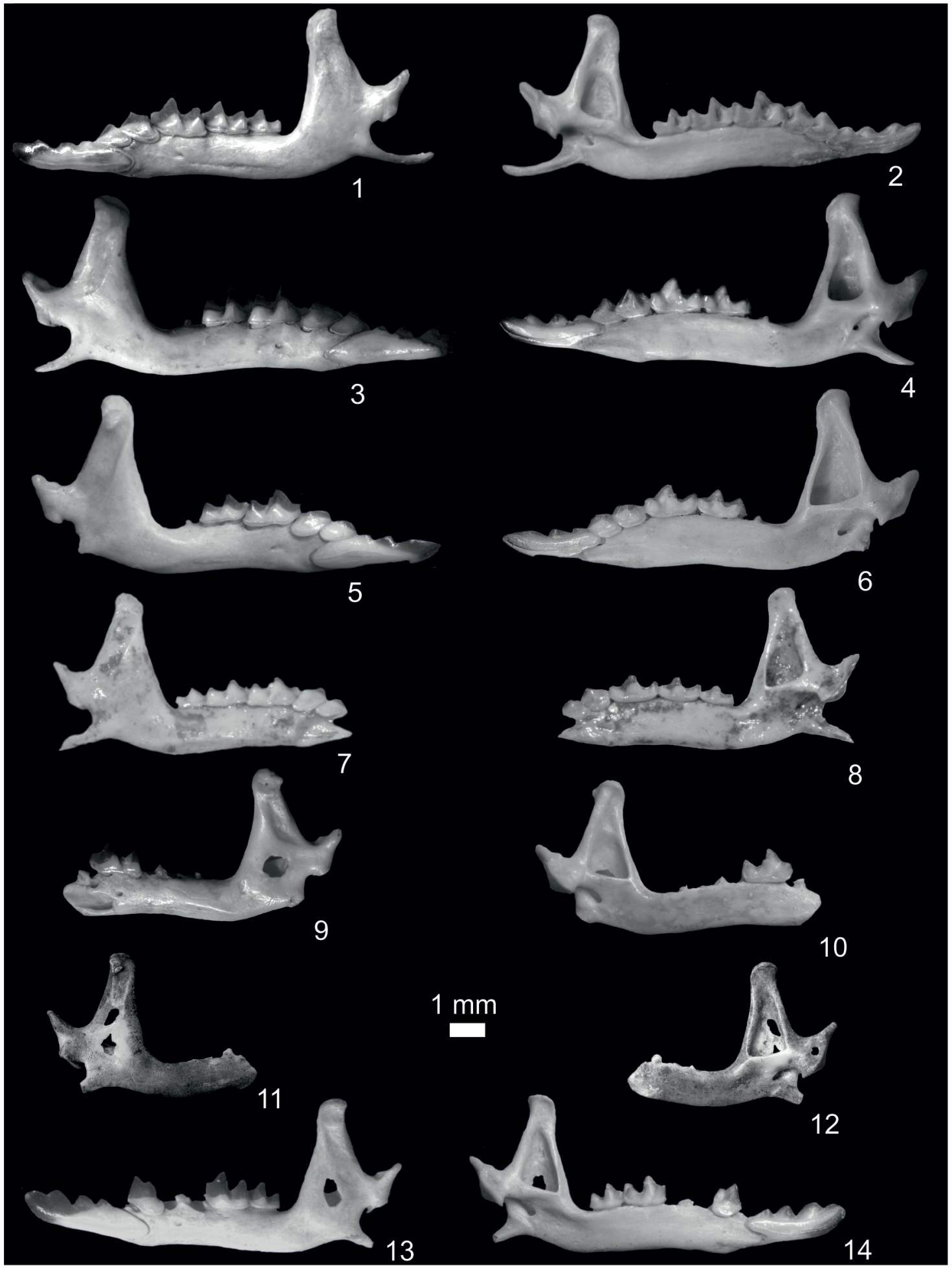

FIGURE 1. Mandibles. Sorex araneus (recent), left, 1 - buccal and 2 - lingual views (no. M/8583). S. araneus (Holocene, Raj Cave, layer 11), right, 3 - buccal and 4 - lingual views (MF/6871/1). Sorex araneus (Late Pleistocene, Obłazowa Cave 2), right, 5 - buccal, 6 - lingual views (MF/6872/1). Sorex subaraneus (Middle Pleistocene, Erpfingen) right, 7 - buccal, 8 - lingual views (Heller 1938/a5). Sorex subaraneus (Early/Middle Pleistocene, Kozi Grzbiet, I. 2A), left, 9 - buccal and 10 - lingual views (MF/1957/15). Sorex runtonensis (Early/Middle Pleistocene, Kozi Grzbiet, banc), right, 11 - buccal and 12 - lingual views (MF/1961/21). Sorex runtonensis (Late Pleistocene/Holocene, Komarowa Cave, I. B), left, 13 - buccal and 14 - lingual views (MF/3184/6). 


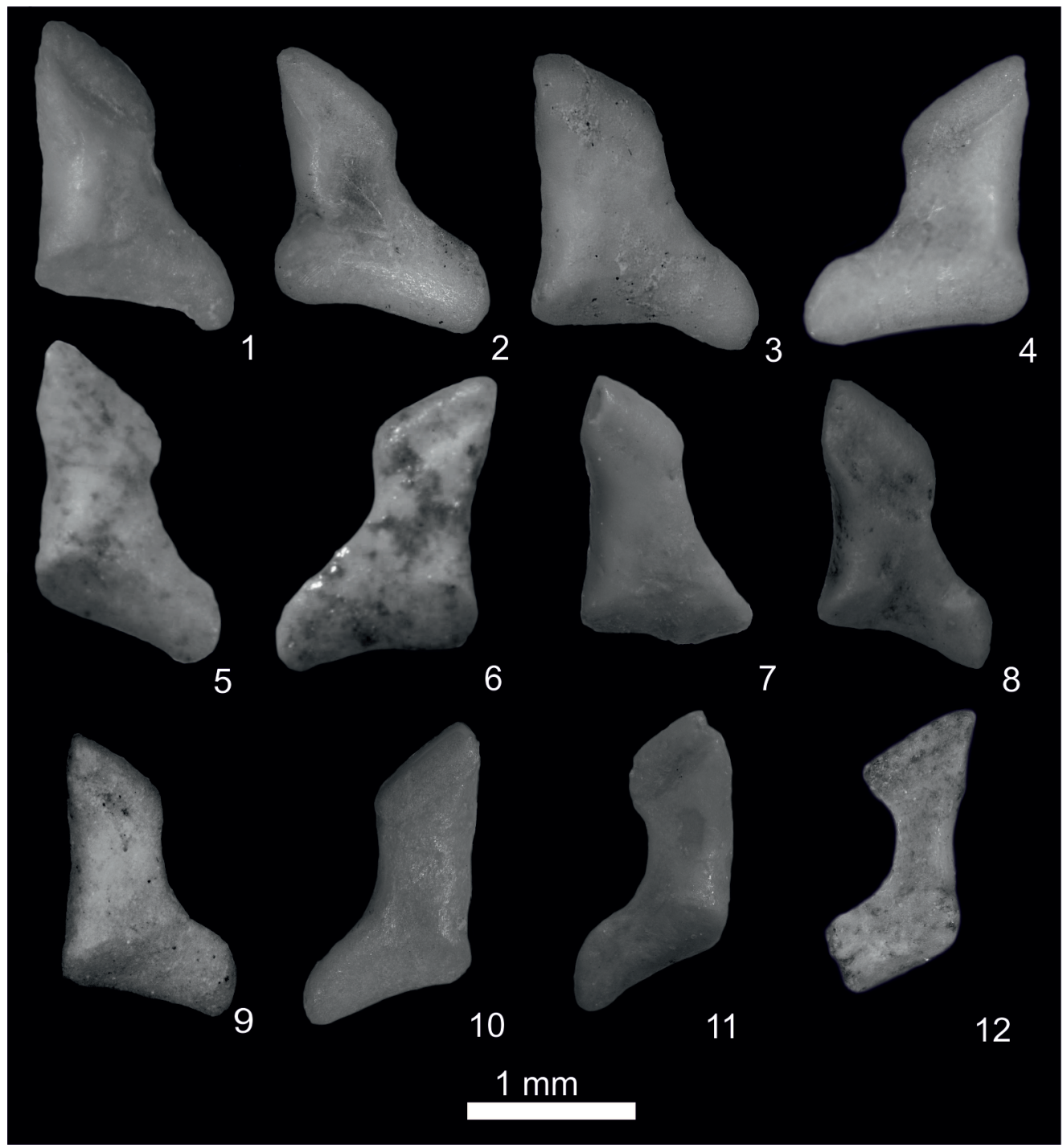

FIGURE 2. Condyloid processes (posterior view) in: 1-2 - Sorex araneus, recent, right (nos. M/8583 and M/ 4707) respectively; 3 - S. araneus, Holocene, Józefów, right (MF/629/1); 4 - S. araneus, Late Pleistocene, Obłazowa 2, left (MF/6872/1); 5-6 - S. subaraneus, Middle Pleistocene, Erpfingen, right and left (Heller 1938/a8 and b5), respectively; 7-8 -S. subaraneus, Early/Middle Pleistocene, Kozi Grzbiet, Is. 2A and 2C, right (MF/1957/15 and 18) respectively; 910 - S. runtonensis, Pleistocene/Holocene, Komarowa Cave, Is. B and D, right and left (MF3184/6 and 49), respectively; 11-12 - S. runtonensis, Early/Middle Pleistocene, Kozi Grzbiet, Is. 2A and heap (MF/1961/4 and 21), respectively.

mens agreed with the morphology of the described left mandible (holotype) from the typical locality. A new detailed description of the typical material has been made for the purpose of this paper.

Redescription of the type material. There is no i1 in the type material. Among two specimens with the a1 present in the collection, one of them is unicuspide, and the other is much too worn to recognize the presence or absence of a second cusp that, if present, is always very small. The posterolingual basin of a1 is shallow. The p4 is two-cusped and its postero-lingual basin is deeper than in a1.
The buccal and lingual cingula of both teeth are broad.

The buccal re-entrant valley of the lower molars (m1, m2) opens at a small distance above the buccal cingulum. The metaconids are equal or wider than the entoconids. The entoconid crest is high but not very long. The buccal cingulum in $\mathrm{m} 1$ is not very wide and slightly undulating, the lingual one is wider and straight. The $\mathrm{m} 2$ is similar to $\mathrm{m} 1$ but smaller, however both of its cingula are wide and straight. The $\mathrm{m} 3$ is relatively big and unreduced. The lower margin of the horizontal ramus is 


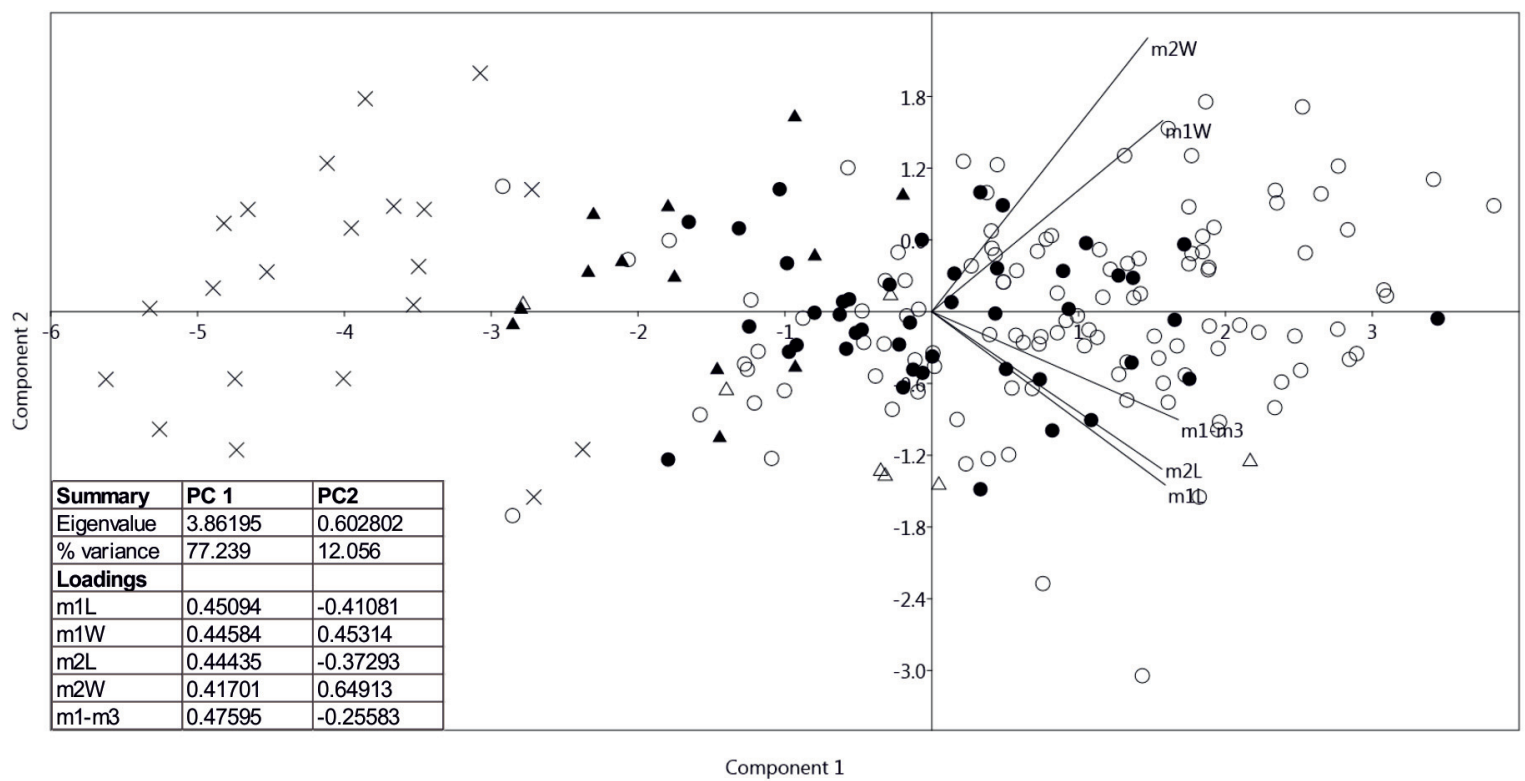

FIGURE 3. Principal component analysis of the lower dentition showing plots of components 1 against 2 and the table of results of the PCA from PC1 and PC2. Measurements: $L$ and W (max.) of $\mathrm{m} 1$ and $\mathrm{m} 2$ and $\mathrm{L}$ of $\mathrm{m} 1-\mathrm{m} 3$. $\Delta-S$. subaraneus (Germany), $\boldsymbol{\Delta}$ - S. subaraneus (Poland), o - S. araneus (fossil), $\bullet-S$. araneus (recent), $\mathrm{x}-\mathrm{S}$. runtonensis.

slightly concave under the $\mathrm{m} 2$. The tip of the coronoid process is rounded or a bit pointed and bends slightly towards the inside. The external temporal fossa is well developed, and it extends to the upper sigmoid notch or slightly underneath it. It is deeper below the coronoid spicule, which is not distinct. The mental foramen is situated below the trigonid of $\mathrm{m} 1$. The internal temporal fossa is high in the shape of an isosceles triangle and in majority of specimens provided with a horizontal bar. Two mandibular foramina are present. They are situated below the posterior corner of the internal temporal fossa. The condyloid process is generally high, its upper facet is cylindrical and the lower facet wide. The interarticular area is wider in its lower part.

Measurements. See Tables 1, 2 and Appendix 2, Table 1.

Individual variation. Tooth morphotypes in Sorex subaraneus from Germany were not found. In the material only seven specimens with $\mathrm{m} 1$ and $\mathrm{m} 2$ were present. Five of them $(71.43 \%)$ had a larger metaconid while in the remaining two were more or less equal. There are only five mandible fragments with the mental foramen present. In three of them, it is situated anterior of the protoconid tip of the $\mathrm{m} 1$, in one below it, and in one specimen it is behind the tip. In 18 mandibles with internal temporal fossa, 15 (83.33\%) show a more or less visible bar, the remaining ones do not present it. In seven specimens with the condyloid process, the interarticular area has a trapezoidal shape.

Sorex subaraneus Heller, 1958 (from Poland) Figures 1.9-10, 2.7-8, 3, 4, 5, 6, Appendix 3,

Figures 1. 6, 2.2

Material. It contains upper and lower jaws with teeth and processes from four localities: Kadzielnia 1 and Przymiłowice 3A (Early Pleistocene), Kozi Grzbiet (Early/Middle Pleistocene) and Rębielice Królewskie 4 (Middle Pleistocene), Appendix 1.

Description of the material. Extensive data on the morphology and measurements of $S$. subaraneus from Poland can be found in Rzebik-Kowalska (1991). This paper presents only features not mentioned by Heller (1958) and Rzebik-Kowalska (1991). Description of upper teeth - Appendix 4. The a1 is not shifted forwards and (as in $S$. araneus) in buccal view the distance between the posterior edges of $\mathrm{i} 1$ and $\mathrm{a} 1$ is equal to or smaller than the distance between the posterior edge of i1 and the anterior edge of the paraconid of $\mathrm{m} 1$ (Table $3)$.

The remaining characters of the mandible and their variation are similar to those from Erpfingen. For example, in more than half $(57.14 \%)$ of all specimens the mental foramen is situated behind the protoconid tip of the $\mathrm{m} 1$ (in 14 of them considerably and in 3 even further behind it), in $26.99 \%$ 


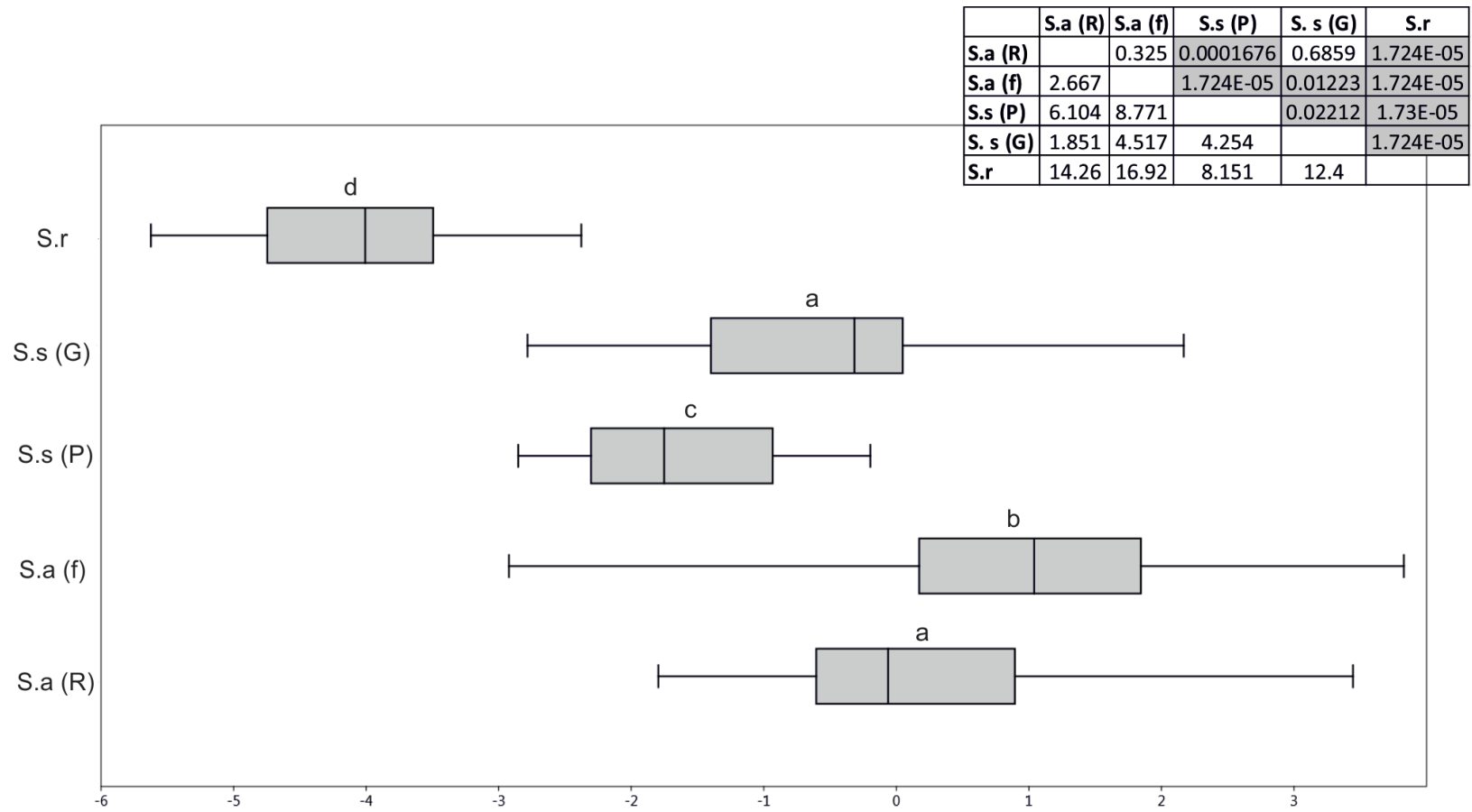

FIGURE 4. Box Plot with the mediana the maximum - minimum values and $25-75 \%$ quartiles from PC1 of the lower dentition. S.s (G) - S. subaraneus (Germany); S.s (P) - S. subaraneus (Poland); S.a (R) - S. araneus (recent); S.a (f) $-S$. araneus (fossil); $S$. $r(P)-S$. runtonensis. The same letters indicate no significant differences between the groups compared.

below and in $15.87 \%$ in front of this tip. In most $(82.35 \%)$ specimens with internal temporal fossa the bar, more or less prominent, is present, but in others it is absent. The shape of the interarticular area of the condyloid process is trapezoidal in 13 of $14(92.86 \%)$ of specimens and in only one specimen it is rather rectangular shape.

The position of the a1 in the mandible (more anterior or more posterior) cannot be established because of the lack of i1 in the studied mandibles. Also, the size of the metaconid in comparison with the entoconid in lower molars ( $\mathrm{m} 1$ and $\mathrm{m} 2)$ is similar in both (Polish and German) populations. In $60.71 \%$ the metaconid was larger than the entoconid, in $35.71 \%$ more or less equal to the entoconid and in only two specimens $(3.58 \%)$ it was smaller than the entoconid.

Measurements. Tables 1-4 and Appendix 2, Tables 1-4.

Differences between typical $S$. subaraneus from Erpfingen and $S$. subaraneus from Poland. As it can be seen from Table 1, the Polish $S$. subaraneus is slightly smaller. Moreover, its a1 shows a trace of a second cusp while the two a1 present in the Erpfingen material are singlecusped. Also, the entoconid crest of the lower molars is slightly shorter in specimens from Poland and these teeth, especially $\mathrm{m} 2$, can present mesoconids that are absent in the seven $\mathrm{m} 1$ and five $\mathrm{m} 2$ present in material from Erpfingen.

\section{Sorex araneus Linnaeus, 1758 (extant from Poland)}

Figures 1.1-2, 2. 1-2, 3, 4, 5, 6, Appendix 3,

Figures 1.1, 2.1

Material. 50 upper and lower jaws with the dentition and processes, all from Poland, Appendix 1.

Description of the material. Description of upper teeth - Appendix 4.

The i1 is long and tricuspulate. Its cusps diminish from the first situated near the apex to the last placed near the tooth talonid. The apex is upturned. The cingulum is rather wide and it is present along the postero-buccal border. The a1 is relatively long and unicuspid. It is not shifted forwards. In buccal view, the distance between the posterior edges of $\mathrm{i} 1$ and a1 is always equal to or smaller than the distance between the posterior edge of $\mathrm{i} 1$ and the anterior edge of the paraconid of $\mathrm{m} 1$ (Table 3 ). Its posterolingual basin is very shallow. Clear and wide cingula occur on both sides of the tooth. 


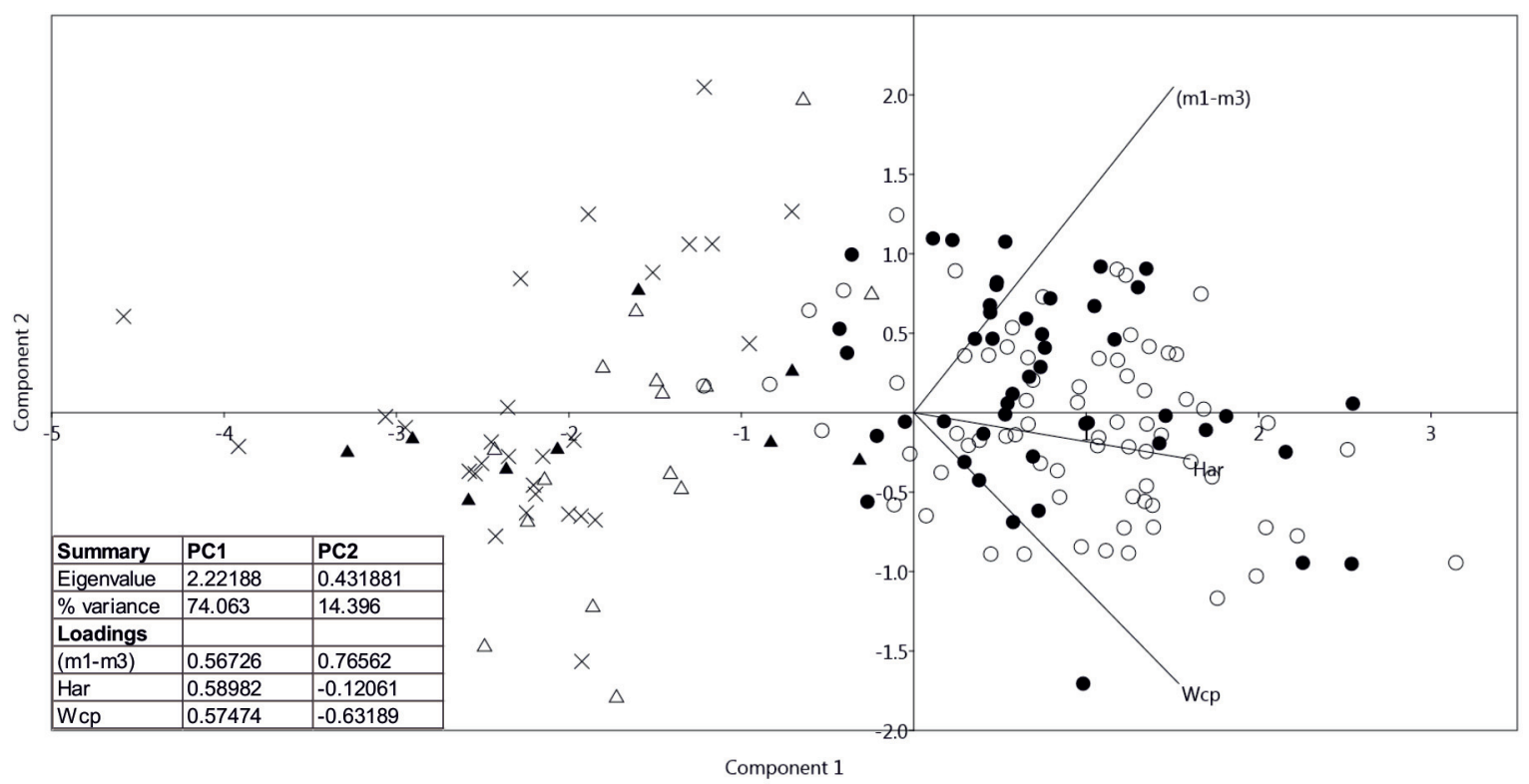

FIGURE 5. Principal component analysis of the mandible, showing plots of components 1 against 2 and the table of results of the PCA from PC1 and PC2. Measurements: $L$ of $m 1-m 3$ alveoli, $H$ of ascending ramus and $W$ of coronoid process. $\Delta$ - S. subaraneus (Germany), $\Delta$ - S. subaraneus (Poland), o - S. araneus (fossil), $\bullet-S$. araneus (recent), $\mathrm{x}$ - S. runtonensis.

The p4 is two-cusped. The anterior cusp is always much higher than the posterior one. The postero-lingual basin is deep and bordered by sharp crests. Clear and wide cingula are also present on both sides of the tooth. The $\mathrm{m} 1$ and $\mathrm{m} 2$ are similar in morphology, but $\mathrm{m} 2$ is smaller. The highest cusp of both teeth is the protoconid. Their buccal re-entrant valley opens at some distance above the buccal cingulum. On the lingual side, the trigonid valley is narrow and it opens low, the metaconid/entoconid valley is wide and provided with a long and rather high entoconid crest. The metaconid is narrow and entoconid wide, more so than the metaconid, the hypolophid is situated very close to the entoconid and there is no groove between the entoconid and the entostylid. In some specimens, weak mesoconids are visible. A cingulum is present all around the molars. The buccal cingulum is more protruded. The $\mathrm{m} 3$ has a well developed long and basined talonid. The hypoconid and entoconid are small. The postero-lingual cingulum is poorly visible.

In general, the horizontal ramus of the mandible is slightly concave below $\mathrm{m} 1 / \mathrm{m} 2$ and the mental foramen is situated below the trigonid of the $\mathrm{m} 1$. The ascending ramus is high. The anterior edge of the coronoid process is straight or more or less concave. The posterior one is rather concave. The tip of the coronoid process is wide, rounded and it leans slightly towards the posterior and lingual sides. The coronoid spicule is developed to various degrees and situated close to the tip of the process. The external temporal fossa is shallow and developed as a longitudinal groove running parallel to the posterior edge of the coronoid process. It is deeper below the coronoid spicule. It reaches to the upper sigmoid notch or slightly lower. The pterygoid spicule (boss) is small or absent, rarely better developed. The internal temporal fossa is high in the shape of an isosceles triangle but it does not continue to the tip of the coronoid process. In some specimens, it is provided with a horizontal bar separating the shallow upper part from the deep lower part of the fossa. Two (rarely one or three) mandibular foramina are situated below the lower edge of the internal temporal fossa. They are more or less equal in size or the upper one (situated below the posterior corner of the internal temporal fossa) is much smaller.

In general, the condyloid process is low. Its upper facet is cylindrical, the lower facet is wide and slightly concave lingually. Its interarticular area is narrow in the upper side and wider in the lower side. It does not reach the end of the lower facet. 


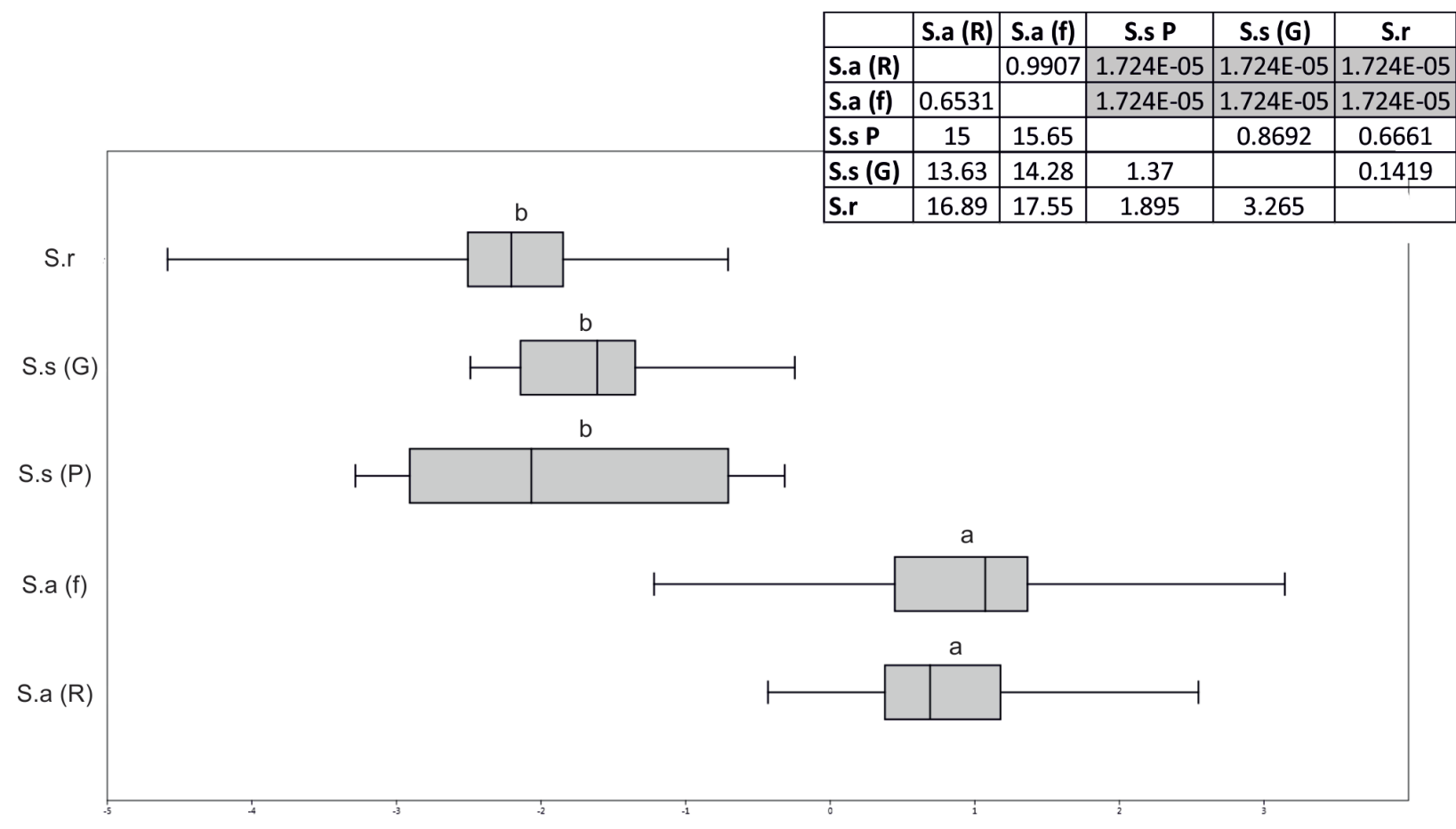

FIGURE 6. Box Plot with the mediana the maximum - minimum values and $25-75 \%$ quartiles from PC1 of the mandible. S.s (G) - S. subaraneus (Germany); S.s (P) - S. subaraneus (Poland); S.a (R) - S. araneus (recent); S.a (f) - S. araneus (fossil); $S$. $r(P)-S$. runtonensis. The same letters indicate no significative differences between the groups compared.

Measurements. Tables 3, 5 and Appendix 2, Table 5.

Individual variation. Individual variation in the recent Sorex araneus concerns some characters in 11, P4, M2, the position of the mental foramen, number of mandibular foramina, the presence of a bar in the internal temporal fossa and the morphology of the condyloid process.

The upper margin of 11 can be straight or slightly convex. The posterior buccal edge is placed at a sharp or right angle to the dorsal margin and the posterior buccal cingulum can be more or less undulating. The parastylar crest of P4 can be longer or shorter and in some individuals is hardly visible. It is horizontal or oblique (raising from the parastyle towards the paracone). The cingular cusp situated between the parastyle and the protocone can be conspicuous, small or hardly discernible. Among 49 studied specimens it was present in 37 (about $75.5 \%$ ). In most individuals, the $\mathrm{M} 2$ is rectangular in occlusal view, but in some of them it can also be more or less square.

In most specimens (about 49\%), the mental foramen is situated slightly more to the back of the tip of the $\mathrm{m} 1$ protoconid. In the remaining cases, it is situated below the tip of the protoconid $(30 \%)$ or slightly anterior of it (21\%). In two of 100 studied specimens, it lies as far as the reentrant valley of $\mathrm{m} 1$. There is also variability in the presence of the mandibular foramina. Usually there are two present in both halves of the mandible $(82.35 \%$ of specimens). However, specimens with one foramen in each half were also found, one in one half and two in the second half, and in one individual there were three mandibular foramina in both halves of the mandible. As mentioned above, they are equal in size or one of them (the posterior one) is smaller or very small. Concerning the presence of the horizontal bar in the internal temporal fossa, the most frequent condition (about 59.68\%) is a lack of this structure in both halves of the mandible. In other specimens, distinct or weak bar can be found in both halves of the mandible or the bar is present in one half and absent from the other. The coronoid spicule and the pterygoid boss can be more or less distinct. The condyloid process is also slightly variable. It can be higher than usual; its lower facet can be longer or shorter and narrower or wider and the interarticular area more trapezoidal or more rectangular in shape. However, trapezoidal interarticular area prevailed $(77.55 \%)$. 
TABLE 1. Dimensions (in $\mathrm{mm}$ ) of mandible and lower teeth of Sorex subaraneus from Poland and Germany.

\begin{tabular}{|c|c|c|c|c|c|c|c|c|c|c|c|c|}
\hline & \multicolumn{12}{|c|}{ Sorex subaraneus } \\
\hline & \multicolumn{6}{|c|}{$\begin{array}{c}\text { Kadzielnia 1, Elary Pleistocene } \\
\text { Przymiłowice 3A, Early Pleistocene } \\
\text { Kozi Grzbiet, Elary/Middle Pleistocene } \\
\text { Rębielice Królewskie 4, Middle Pleistocene } \\
\text { Poland }\end{array}$} & \multicolumn{6}{|c|}{$\begin{array}{c}\text { Erpfingen, Middle Pleistocene } \\
\text { (measured by Dr L. Maul) } \\
\text { Germany }\end{array}$} \\
\hline & Min & $\mathbf{X}$ & Max. & $\mathbf{N}$ & sd & cv & Min. & $\mathbf{X}$ & Max. & $\mathbf{N}$ & sd & cv \\
\hline $\mathrm{i} 1 \mathrm{~L}$ & 3.37 & 3.52 & 3.66 & 18 & 0.09 & 2.56 & - & - & - & - & - & - \\
\hline i1 W & 0.71 & 0.85 & 0.94 & 37 & 0.05 & 5.88 & - & - & - & - & - & - \\
\hline a1 L (bucc.) & 0.82 & 0.95 & 1.05 & 14 & 0.06 & 6.32 & - & - & - & - & - & - \\
\hline p4 L & 0.89 & 1.03 & 1.14 & 34 & 0.06 & 5.82 & 0.93 & 0.96 & 0.99 & 2 & - & - \\
\hline p4 W & 0.65 & 0.73 & 0.80 & 32 & 0.04 & 5.48 & 0.69 & 0.71 & 0.73 & 2 & - & - \\
\hline $\begin{array}{l}\mathrm{m} 1 \mathrm{~L} \\
\mathrm{~m} 1 \mathrm{~W}\end{array}$ & $\begin{array}{l}1.35 \\
0.80\end{array}$ & $\begin{array}{l}1.43 \\
0.85\end{array}$ & $\begin{array}{l}1.49 \\
0.98\end{array}$ & $\begin{array}{l}60 \\
61\end{array}$ & $\begin{array}{l}0.03 \\
0.03\end{array}$ & $\begin{array}{l}2.10 \\
3.53\end{array}$ & $\begin{array}{l}1.41 \\
0.82\end{array}$ & $\begin{array}{l}1.55 \\
0.86\end{array}$ & $\begin{array}{l}1.66 \\
0.93\end{array}$ & $\begin{array}{l}7 \\
7\end{array}$ & $\begin{array}{l}0.09 \\
0.03\end{array}$ & $\begin{array}{l}5.81 \\
3.49\end{array}$ \\
\hline m2 L & 1.18 & 1.25 & 1.30 & 46 & 0.03 & 2.40 & 1.25 & 1.33 & 1.40 & 5 & - & - \\
\hline $\mathrm{m} 2 \mathrm{~W}$ & 0.73 & 0.78 & 0.87 & 45 & 0.03 & 3.85 & 0.75 & 0.79 & 0.86 & 5 & - & - \\
\hline m3 L & 0.95 & 1.04 & 1.11 & 27 & 0.04 & 3.85 & 0.99 & 1.04 & 1.13 & 4 & - & - \\
\hline m3 W & 0.56 & 0.62 & 0.67 & 27 & 0.03 & 4.84 & 0.64 & 0.68 & 0.78 & 4 & - & - \\
\hline m1-m3 L & 3.57 & 3.66 & 3.78 & 16 & 0.06 & 1.64 & 3.52 & 3.66 & 3.80 & 4 & - & - \\
\hline m1-m3 L (alveol.) & 3.21 & 3.32 & 3.48 & 7 & 0.11 & 3.31 & 3.12 & 3.35 & 3.70 & 15 & 0.17 & 5.07 \\
\hline $\mathrm{H}$ of mandible below $\mathrm{m} 2$ & 1.15 & 1.24 & 1.33 & 48 & 0.05 & 4.03 & - & - & - & - & - & - \\
\hline $\mathrm{H}$ of ascending ramus & 3.80 & 4.21 & 4.54 & 18 & 0.19 & 4.51 & 4.01 & 4.32 & 4.64 & 18 & 0.13 & 3.01 \\
\hline W of coronoid process & 0.70 & 0.88 & 1.00 & 19 & 0.07 & 7.95 & - & - & - & - & - & - \\
\hline $\mathrm{H}$ of condyloid process & 1.57 & 1.72 & 1.87 & 5 & 0.12 & 6.98 & 1.44 & 1.65 & 1.84 & 17 & 0.10 & 6.06 \\
\hline W of interarticular area & 0.50 & 0.57 & 0.66 & 12 & 0.05 & 8.77 & - & - & - & - & - & - \\
\hline
\end{tabular}

S. araneus Linnaeus, 1758 (fossil from Poland) Figures 1.3-6, 2.3-4, 3, 4, 5, 6, Appendix 3, Figures 1.2-5

Material. It contains about 500 upper and lower jaws with teeth and processes from 17 localities dated from the Late Middle Pleistocene to the Early Holocene. Appendix 1.

Description of the material. Description of upper teeth is given in Appendix 4. In Poland, the sizes of the fossil specimens of Sorex araneus from the Middle Pleistocene to the Early Holocene do not practically differ. The ranges of their dimensions and averages of all dimensions are similar if not the same. They are also similar to the dimensions of the recent form. Apparently, $S$. araneus has not enlarged its dimension in geological time (Table 5 and Appendix 2, Tables 5-6).

Moreover, the morphology of the fossil Sorex araneus does not differ from the recent form. Just as in recent $S$. araneus some characters can appear in different intensity, change their position slightly or sometimes they are present or absent, and the percentage of these changes can be somewhat different in populations representing different periods of time.
Individual variations. As concerns the mandible, Sorex araneus from the late Middle Pleistocene (Nietoperzowa Cave, Is.14-15) differs from others by the position of the mental foramen. In most specimens, this foramen is situated slightly in front of $(42.86 \%)$ or below $(50 \%)$ the tip of the protoconid of $\mathrm{m} 1$. In younger (Late Pleistocene to recent) specimens it lies rather behind (between 49 $66.67 \%$ of specimens) this tip.

The number of mandibular foramina also differs in Nietoperzowa Cave (Is.15-14) because $33.33 \%$ of mandibles exhibit one foramen while in the remaining specimens it does not exceed $25 \%$. In most $(66.67-82.35 \%)$ of fossil and recent specimens of $S$. araneus two mandibular foramina are present. The bar in the internal temporal fossa is present more frequently in specimens from the late Middle and Late Pleistocene (66.67 and 67.42\% respectively), and less often in the Holocene and recent mandibles (37.78 and $40.32 \%$, respectively). In the fossil specimens the interarticular area of the condyloid process is close to trapezoid shape in $95.90 \%-100 \%$ but in recent specimens in only about $77.55 \%$. The remaining ones are more or less rectangular. 
TABLE 2. Comparison of dimensions (in $\mathrm{mm}$ ) of Sorex runtonensis from Poland and Sorex subaraneus from Poland and Germany with Sorex satunini from Russia.

\begin{tabular}{|c|c|c|c|c|c|c|c|c|c|c|c|c|c|c|c|c|c|c|c|c|}
\hline & \multicolumn{4}{|c|}{ S. runtonensis } & \multicolumn{4}{|c|}{ S. subaraneus } & \multicolumn{4}{|c|}{ S. subaraneus } & \multicolumn{4}{|c|}{ S. satunini } & \multicolumn{4}{|c|}{ S. satunini } \\
\hline & \multicolumn{4}{|c|}{$\begin{array}{c}\text { Kozi Grzbiet } \\
\text { Poland } \\
\text { Early/Middle } \\
\text { Pleistocene }\end{array}$} & \multicolumn{4}{|c|}{$\begin{array}{c}\text { Kozi Grzbiet } \\
\text { Poland } \\
\text { Early/Middle } \\
\text { Pleistocene }\end{array}$} & \multicolumn{8}{|c|}{$\begin{array}{c}\text { Treugolnaya Cave } \\
\text { Northern Caucasus } \\
\text { Russia } \\
\text { Middle Pleistocene } \\
\text { Zaitsev and } \\
\text { Baryshnikov (2002) }\end{array}$} & \multicolumn{4}{|c|}{$\begin{array}{c}\text { Northern Caucasus } \\
\text { Russia } \\
\text { recent } \\
\text { Zaitsev and } \\
\text { Baryshnikov (2002) }\end{array}$} \\
\hline & Min. & $\mathbf{X}$ & Max. & $\mathbf{N}$ & Min. & $\mathbf{X}$ & Max. & $\mathbf{N}$ & Min. & $\mathbf{X}$ & Max. & $\mathbf{N}$ & Min. & $\mathbf{X}$ & Max. & $\mathbf{N}$ & Min. & $\mathbf{X}$ & Max. & $\mathbf{N}$ \\
\hline i1 L & 3.21 & 3.39 & 3.56 & 11 & 3.37 & 3.52 & 3.66 & 17 & - & - & - & - & - & - & - & - & 3.60 & 3.72 & 3.90 & 14 \\
\hline $\begin{array}{l}\text { a1 L } \\
\text { (buc.) }\end{array}$ & 0.84 & 0.87 & 0.88 & 4 & 0.82 & 0.94 & 1.05 & 12 & - & - & - & - & 1.00 & 1.07 & 1.10 & 3 & 0.85 & 1.00 & 1.05 & 14 \\
\hline $\mathrm{m} 1 \mathrm{~L}$ & 1.30 & 1.36 & 1.43 & 39 & 1.35 & 1.43 & 1.49 & 56 & 1.41 & 1.45 & 1.66 & 7 & 1.45 & 1.48 & 1.50 & 4 & 1.40 & 1.45 & 1.50 & 14 \\
\hline m1-m3 L & 3.40 & 3.49 & 3.59 & 16 & 3.57 & 3.69 & 3.95 & 16 & 3.52 & 3.66 & 3.80 & 4 & & 3.80 & & & 3.65 & 3.74 & 3.85 & 14 \\
\hline $\begin{array}{l}\mathrm{H} \text { of } \\
\text { mandible } \\
\text { below m2 }\end{array}$ & 1.03 & 1.12 & 1.22 & 39 & 1.12 & 1.24 & 1.33 & 42 & - & - & - & - & 1.25 & 1.29 & 1.35 & 4 & 1.15 & 1.28 & 1.35 & 14 \\
\hline $\begin{array}{l}\mathrm{H} \text { of } \\
\text { ascending } \\
\text { ramus }\end{array}$ & 3.66 & 3.89 & 4.21 & 7 & 3.94 & 4.21 & 4.54 & 15 & 4.01 & 4.32 & 4.64 & 18 & 4.35 & - & 4.40 & 2 & 4.20 & 4.41 & 4.60 & 14 \\
\hline $\begin{array}{l}\text { W of } \\
\text { coronoid } \\
\text { process }\end{array}$ & 0.70 & 0.77 & 0.88 & 8 & 0.79 & 0.88 & 1.00 & 16 & - & - & - & - & 1.00 & 1.03 & 1.05 & 2 & 0.90 & 1.01 & 1.10 & 14 \\
\hline $\begin{array}{l}\text { W of } \\
\text { interarticu } \\
\text { lar area }\end{array}$ & 0.45 & 0.52 & 0.56 & 6 & 0.52 & 0.58 & 0.66 & 11 & - & - & - & - & - & 0.65 & - & 2 & 0.65 & 0.68 & 0.75 & 14 \\
\hline
\end{tabular}

Measurements. Tables 3, 5 and Appendix 2, Table 6.

Sorex runtonensis Hinton, 1911 (from Poland)

Figures 1.11-14, 2.9-12, 3, 4, 5, 6, Appendix 3, Figure 1.7

Material. The list of the material is cited in the Appendix 1. It contains 64 upper and lower jaws with teeth and processes from six localities: Kozi Grzbiet (Early/Middle Pleistocene), Żabia Cave (Early Pleistocene), Raj Cave (Is. 1-10), Krucza Skała Rock Shelter (Is. 1-8 and I-V) (Late Pleistocene) and Komarowa Cave (Late Pleistocene/ Holocene).

Description of the material. The description of the Sorex runtonensis holotype from the locality West Runton (England) was made by Hinton in 1911. This description was later completed by Harrison (1996). A detailed description of the Polish $S$. runtonensis is available in Rzebik-Kowalska (1991). In 2002, Zaitsev and Baryshnikov added that the comparatively small and low a1 of this species is considerably shifted forwards. In buccal view, the distance between the posterior edges of a1 and i1 is greater than that between the posterior edge of $\mathrm{i} 1$ and the paraconid of $\mathrm{m} 1$. This a1 dis- placement was not observed earlier by researchers of this species, however it is conspicuous in Polish $S$. runtonensis and not found in other species ( $S$. subaraneus, S. araneus and $S$. satunini) studied here.

On the fossil S. runtonensis and recent $S$. tundrensis there was a discussion in the paper of Osipova et al. (2006). The authors have pointed that the size and morphology of both species are very similar, and it is very probable that they are conspecific and their names should be treated as synonyms. On the other hand, it is highly probable that $S$. tundrensis "could be considered as a species complex that includes forms of different taxonomic levels." Besides, a considerably spatial gap between the known ranges of the two forms (Western Palearctic - S. runtonensis and Eastern Palearctic - S. tundrensis) does not allow, for the time being, synonymizing these two forms.

However, Prost et al. (2013) described Sorex cf. tundrensis from the German cave Sesselfels, the locality dated to the Late Pleistocene (Weichselian, about 60000 year BP) a few years later. Because authors failed to obtain DNA from the Sesselfels specimens, they based their identification solely on measurements. They did not com- 
TABLE 3. Position of a1 in comparison with other teeth ( $\mathrm{L}$ in $\mathrm{mm}$, Zaitsev and Baryshnikov, 2002).

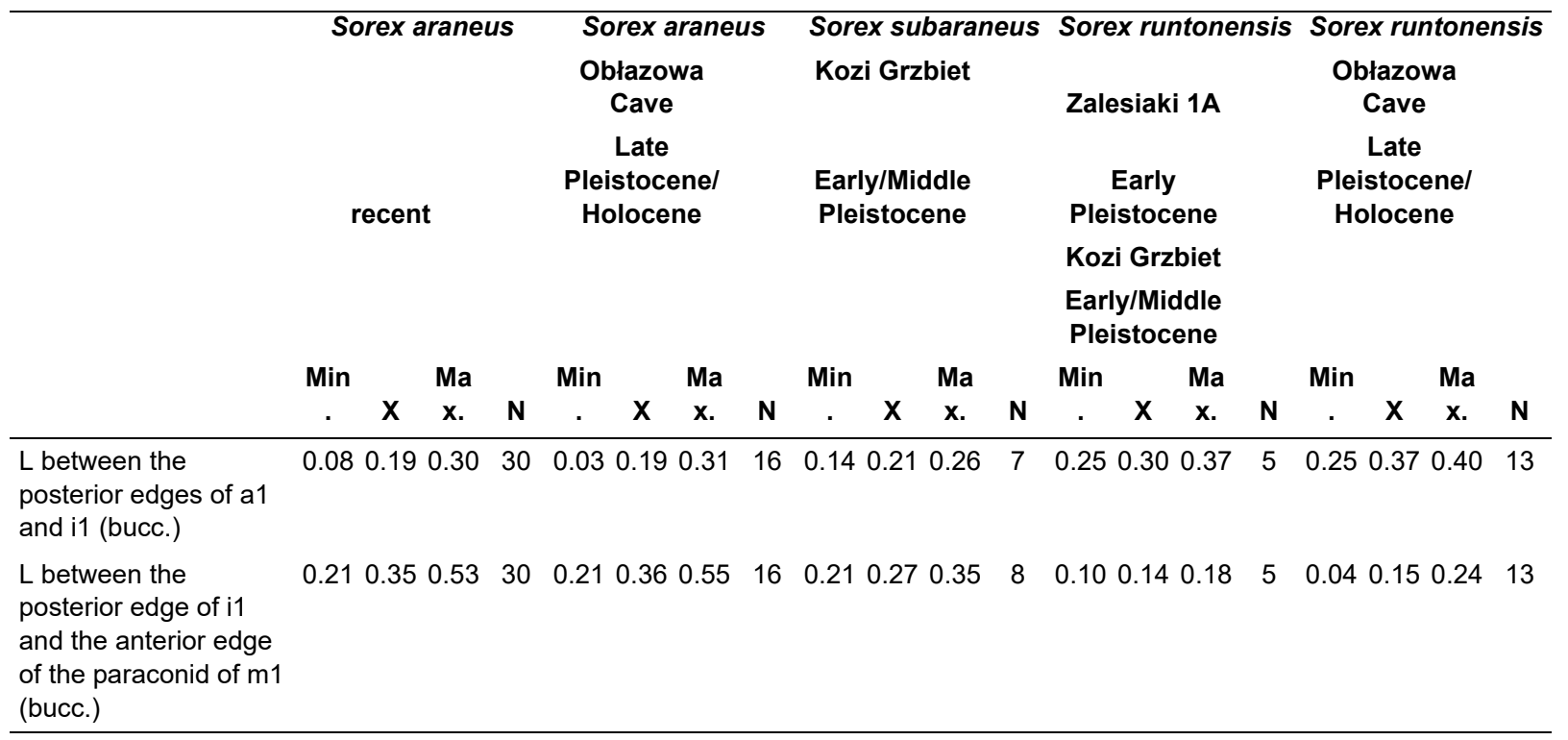

pare these specimens with fossil European species (of similar size and morphology e.g., with S. subaraneus and particularly with widely distributed at that time in Europe and in Germany S. runtonensis) but compared them with $S$. tundrensis from Eastern Palearctic. Besides, they only compared their coronoid height and length of condyloid process with these dimensions in recent $S$. tundrensis from Russia. The attached photos in Prost et al. (2013, Supporting Information, figure S2) show, however, that remains from Sesselfels cave are more similar to $S$. subaraneus rather than to $S$. runtonensis and $S$. tundrensis. The shape of the coronoid processes of both forms are quite different - slim in S. tundrensis (narrow at the level of the upper sigmoid notch) and more robust (wide at the level of the upper sigmoid notch) in Sesselfels specimens. It seems really unlikely that the specimens from Sesselfels belong to $S$. tundrensis.

Basing on the DNA of six subfossil specimens of Sorex cf. coronatus from two Austrian localities (Nixloch and Gamssulzen) Prost et al. (2013) also included them into Sorex tundrensis. However, in Supporting Informations the authors wrote: "We would like to note that the presented results have to be treated with some caution as they are based solely on mitochondrial DNA." Considering the above data, we believe that the presence of $S$. tundrensis in Europe has not been sufficiently proven for the time being. Most likely, all these specimens represent $S$. subaraneus.

Measurements. Tables 2-4 and Appendix 2, Table 4.

\section{Sorex satunini Ognev, 1922 (from Russia)}

Material and Description of the material. See Zaitsev and Baryshnikov (2002).

The recent $S$. satunini was described in Russia by Ognev in 1922 (for its taxonomy see Pavlinov and Rossolimo, 1987). The fossil Middle Pleistocene form of this species was found in the Treugolnaya Cave in the North Caucasus and described in the paper of Zaitsev and Baryshnikov (2002). Sorex cf. satunini was cited from other Caucasian caves: from the North Caucasus in Matuzka Cave, Mezmaiskaya Cave, Monasheskaya Cave and Myshtulagty Cave, as well as from the West Caucasus in Kudaro Caves 1 and 3 (all dated to the Late Pleistocene, Osipova, 2006). Nowadays it inhabits northern Turkey and the Caucasus Mountains (Georgia, Russia, Azerbaijan) (Wolsan and Hutterer, 1998).

Measurements. Table 2.

\section{RESULTS}

Sorex subaraneus, especially Polish specimens, differs from fossil and recent $S$. araneus by somewhat smaller size (Tables 1, 4, 5 and Appendix 2, Tables 1-3, 5-6). However, although all minimal and maximal dimensions of $S$. subaraneus are smaller than those in $S$. araneus, its maximal dimensions overlap with dimensions of the latter species. There is not a single dimension that would be smaller and entirely outside the range of variation of $S$. araneus (fossil or recent). The averages 
TABLE 4. Comparison of dimensions (in $\mathrm{mm}$ ) of Sorex subaraneus and Sorex runtonensis from Poland.

\begin{tabular}{|c|c|c|c|c|c|c|c|c|c|c|c|c|c|c|c|c|c|c|}
\hline & \multicolumn{6}{|c|}{ Sorex runtonensis } & \multicolumn{6}{|c|}{ Sorex subaraneus } & \multicolumn{6}{|c|}{ Sorex runtonensis } \\
\hline & \multicolumn{6}{|c|}{$\begin{array}{l}\text { Kozi Grzbiet } \\
\text { Early/Middle Pleistocene }\end{array}$} & \multicolumn{6}{|c|}{$\begin{array}{l}\text { Kozi Grzbiet } \\
\text { Early/Middle Pleistocene }\end{array}$} & \multicolumn{6}{|c|}{$\begin{array}{c}\text { Raj Cave (Is. 1-10), Krucza Skała } \\
\text { Rock Shelter (Is. 1-8 and I-V), Late } \\
\text { Pleistocene, } \\
\text { Komarowa Cave, Late Pleistocene } \\
\text { Holocene }\end{array}$} \\
\hline & Min. & $\mathbf{X}$ & Max. & $\mathbf{N}$ & sd & cv & Min & $\mathbf{X}$ & Max. & $\mathbf{N}$ & sd & cv & Min. & $\mathbf{X}$ & Max. & $\mathbf{N}$ & sd & cv \\
\hline i1 L & 3.21 & 3.39 & 3.56 & 11 & 0.11 & 3.24 & 3.37 & 3.52 & 3.66 & 17 & 0.10 & 2.84 & 3.45 & 3.58 & 3.90 & 6 & - & - \\
\hline i1 W & 0.74 & 0.78 & 0.82 & 14 & 0.03 & 3.85 & 0.71 & 0.84 & 0.93 & 35 & 0.04 & 4.76 & 0.75 & 0.83 & 0.90 & 7 & 0.06 & 7.23 \\
\hline $\begin{array}{l}\text { a1 L } \\
\text { (buccal) }\end{array}$ & 0.84 & 0.87 & 0.88 & 4 & - & - & 0.82 & 0.94 & 1.05 & 12 & 0.06 & 6.38 & 0.94 & 0.99 & 1.08 & 4 & - & - \\
\hline $\mathrm{p} 4 \mathrm{~L}$ & 0.78 & 0.98 & 1.05 & 15 & 0.07 & 7.14 & 0.89 & 1.02 & 1.14 & 33 & 0.05 & 4.90 & 0.94 & 1.04 & 1.10 & 14 & 0.05 & 4.81 \\
\hline $\mathrm{p} 4 \mathrm{~W}$ & 0.58 & 0.69 & 0.75 & 15 & 0.05 & 7.25 & 0.65 & 0.72 & 0.80 & 31 & 0.04 & 5.56 & 0.67 & 0.72 & 0.78 & 13 & 0.04 & 5.55 \\
\hline $\mathrm{m} 1 \mathrm{~L}$ & 1.30 & 1.36 & 1.43 & 39 & 0.03 & 2.21 & 1.35 & 1.43 & 1.49 & 56 & 0.03 & 3.00 & 1.32 & 1.41 & 1.46 & 26 & 0.03 & 2.13 \\
\hline $\mathrm{m} 1 \mathrm{~W}$ & 0.75 & 0.81 & 0.87 & 39 & 0.03 & 3.70 & 0.80 & 0.85 & 0.98 & 57 & 0.03 & 3.53 & 0.78 & 0.84 & 0.93 & 26 & 0.03 & 3.57 \\
\hline $\mathrm{m} 2 \mathrm{~L}$ & 1.14 & 1.20 & 1.25 & 39 & 0.03 & 2.50 & 1.18 & 1.25 & 1.30 & 40 & 0.03 & 2.40 & 1.16 & 1.23 & 1.35 & 20 & 0.04 & 3.25 \\
\hline $\mathrm{m} 2 \mathrm{~W}$ & 0.68 & 0.75 & 0.81 & 39 & 0.03 & 4.00 & 0.73 & 0.78 & 0.87 & 39 & 0.03 & 3.85 & 0.69 & 0.76 & 0.84 & 20 & 0.04 & 5.26 \\
\hline m3 L & 0.91 & 0.99 & 1.05 & 20 & 0.03 & 3.03 & 0.95 & 1.04 & 1.11 & 23 & 0.04 & 3.85 & 0.91 & 1.01 & 1.06 & 11 & 0.04 & 3.96 \\
\hline m3 W & 0.56 & 0.59 & 0.63 & 20 & 0.02 & 3.39 & 0.56 & 0.62 & 0.67 & 23 & 0.04 & 4.84 & 0.57 & 0.60 & 0.63 & 11 & 0.02 & 3.33 \\
\hline m1-m3 L & 3.40 & 3.49 & 3.59 & 16 & 0.05 & 1.43 & 3.57 & 3.69 & 3.95 & 16 & 0.10 & 2.71 & 3.53 & 3.63 & 3.72 & 9 & 0.06 & 1.65 \\
\hline $\begin{array}{l}\text { m1-m3 } \\
\text { L(alveol.) }\end{array}$ & 3.23 & 3.27 & 3.31 & 7 & 0.03 & 0.92 & 3.21 & 3.32 & 3.48 & 7 & 0.11 & 3.31 & 3.16 & 3.38 & 3.66 & 23 & 0.14 & 4.14 \\
\hline $\begin{array}{l}\mathrm{H} \text { of } \\
\text { mandible } \\
\text { below } \mathrm{m} 2\end{array}$ & 1.03 & 1.12 & 1.22 & 39 & 0.05 & 4.46 & 1.12 & 1.24 & 1.33 & 42 & 0.05 & 4.03 & 1.14 & 1.25 & 1.36 & 35 & 0.05 & 4.00 \\
\hline $\begin{array}{l}\mathrm{H} \text { of } \\
\text { ascending } \\
\text { ramus }\end{array}$ & 3.66 & 3.89 & 4.21 & 7 & 0.18 & 4.63 & 3.94 & 4.21 & 4.54 & 15 & 0.16 & 3.80 & 3.90 & 4.17 & 4.42 & 31 & 0.12 & 2.88 \\
\hline $\begin{array}{l}\text { W of } \\
\text { coronoid } \\
\text { process }\end{array}$ & 0.70 & 0.77 & 0.88 & 8 & 0.07 & 9.09 & 0.79 & 0.88 & 1.00 & 16 & 0,06 & 6.82 & 0.76 & 0.88 & 1.01 & 32 & 0.07 & 7.95 \\
\hline $\begin{array}{l}\mathrm{H} \text { of } \\
\text { condyloid } \\
\text { process }\end{array}$ & 1.57 & 1.68 & 1.74 & 4 & - & - & 1.57 & 1.72 & 1.87 & 5 & - & - & 1.64 & 1.82 & 1.99 & 20 & 0.11 & 6.04 \\
\hline $\begin{array}{l}W \text { of } \\
\text { interarticula } \\
r \text { area }\end{array}$ & 0.45 & 0.52 & 0.56 & 6 & - & - & 0.52 & 0.58 & 0.66 & 11 & 0.04 & 6.90 & 0.51 & 0.59 & 0.69 & 30 & 0.05 & 8.47 \\
\hline
\end{tabular}

of S. subaraneus are always lower (Tables 1, 5, Appendix 2, Tables 3, 6).

Sorex subaraneus, especially from Erpfingen, differs from $S$. runtonensis by slightly larger size (Tables 1, 4 and Appendix 2, Table 4). It seems clear that the dimensions of $S$. subaraneus are on average larger than the dimensions of S. runtonensis, particularly when both species come from the same locality. For example, in Kozi Grzbiet the $L$ of $\mathrm{m} 1-\mathrm{m} 3$ (in $\mathrm{mm}$ ) in S. subaraneus and S. runtonensis does not overlap at all (Table 2).

The first and second axes of the PCA based on tooth size explain $88.5 \%$ of the total variance (PC1 $74.1 \%$ and $P C 214.4 \%$ ). There is no single measurement that can completely divide the groups. They can be separated only by using a combination of measurements. There is no correlation between the length and the width of the teeth (Figure 3).

The ANOVA analysis performed on the scores of the first axis (the strongest one) shows a significant difference between the studied groups $\left(F_{(4 \text {, }}\right.$ 190) $\left.=82.91, p=6.34 \times 10^{-41}\right)$. It indicates that there are no differences in size between the recent and fossil Sorex araneus from Poland, S. subaraneus from Germany and Poland are only slightly different and $S$. runtonensis is quite different from both above mentioned species (Figure 4). In general, $S$. runtonensis is the smallest, Sorex subaraneus is larger and fossil and recent $S$. araneus are the largest. 


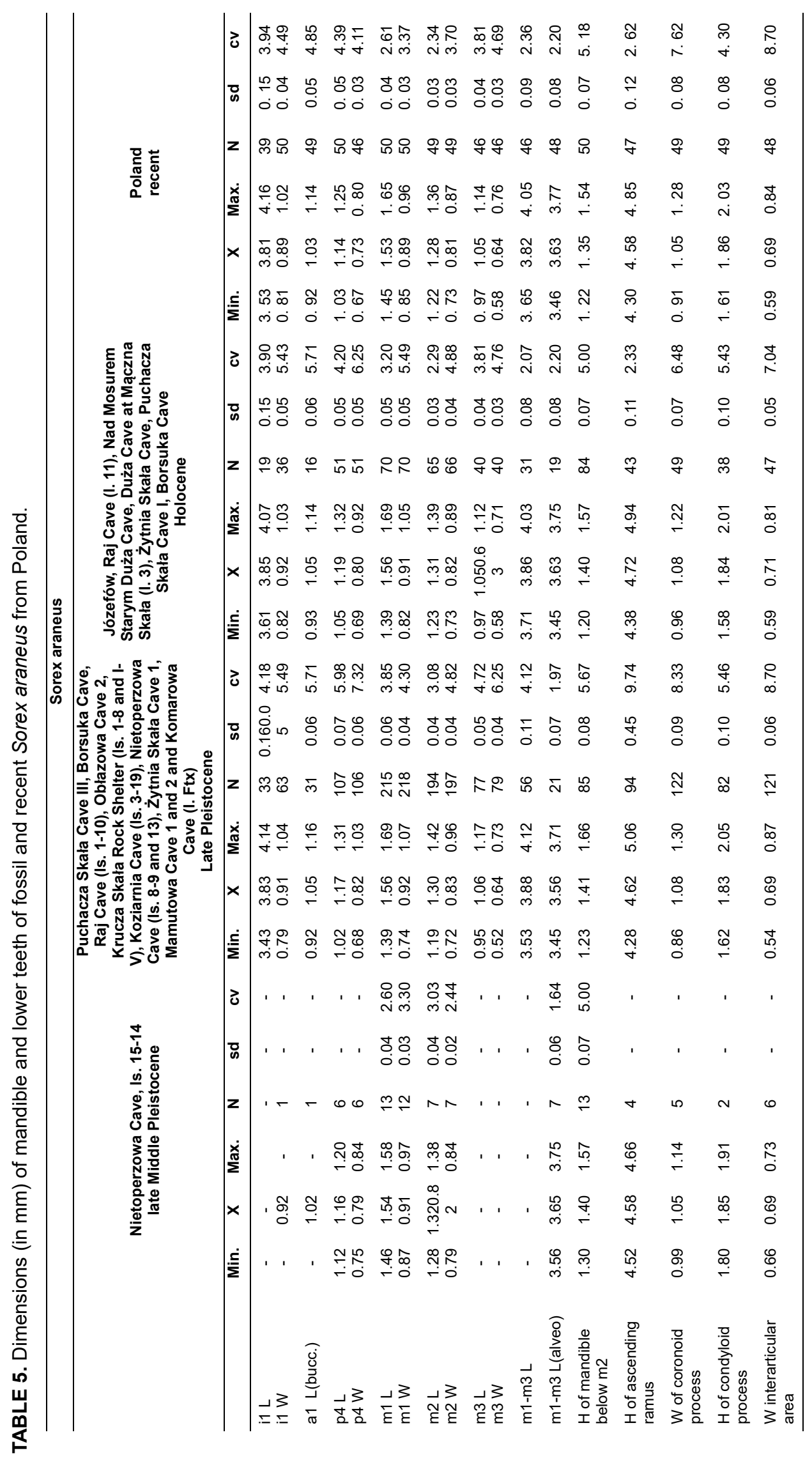


The PCA plot based on three mandible measurements also divided the specimens into groups. The two main axes explain a total $91 \%$ of the observed variance (PC1 77\% and PC2 14\%). The second analysis on the grounds of mandible measurements better separates $S$. araneus from the remaining species (Figure 5 ).

According to the ANOVA, statistical differences exist between groups $\left(F_{(4,156)}=72.27\right.$, $\left.p=9.11 \times 10^{-46}\right)$. Sorex araneus, recent and fossil, are similar to each other, but they differ from all of the other studied species. Sorex subaraneus from Germany and Poland also do not differ from each other. The mandible of $S$. subaraneus seems more delicate than the mandible of $S$. araneus and more similar to the mandible of $S$. runtonensis (Figure 6). However, its teeth are more massive than the teeth of the latter species (Figure 4). The mandible and teeth of $S$. araneus are the largest, and these structures in $S$. runtonensis are the smallest.

As concerns morphology Sorex subaraneus does not differ much from $S$. araneus. As mentioned above, inter-individual variation of particular characters is very similar to this variability in $S$. araneus. However, there are small morphological differences between the two forms. For example, the upper antemolars of $S$. subaraneus have concavities on their antero-lingual sides that are more shallow or even absent in $S$. araneus, and its a1 usually bears a small second cusp (not always, but the second cusp is very small and only seen in unworn teeth) that is completely absent in $S$. araneus. Moreover, the metaconids of lower molars, especially in $\mathrm{m} 1$, are equal or wider than the entoconids, while in $S$. araneus they are always narrower and their entoconid crests are shorter (in $S$. araneus the entoconid crests are long). There are always two mandibular foramina in the mandible of $S$. subaraneus while in $S$. araneus one and even up to three apertures can be found.

The upper teeth of Sorex runtonensis (very rare in the fossil material), especially unicuspids, do not allow for a comparison with upper teeth of $S$. subaraneus. Only metalophs of molars M1 and M2 (numerously found) seem to be somewhat higher in $S$. subaraneus. As concerns lower teeth, the a1 in $S$. subaraneus is not shifted forwards as in $S$. runtonensis. In buccal view, the distance between the posterior edge of $\mathrm{i} 1$ and $\mathrm{a} 1$ is equal to or smaller than the distance between the posterior edge of $\mathrm{i} 1$ and the anterior edge of the paraconid of $\mathrm{m} 1$. In $\mathrm{S}$. runtonensis the a1 is shifted forwards and the distance between the posterior edges of $\mathrm{i} 1$ and $\mathrm{a} 1$ is greater than the distance between the posterior edge of $\mathrm{i} 1$ and the anterior edge of the paraconid of $\mathrm{m} 1$ (Table 3). The mental foramen in the mandible of $S$. subaraneus is often situated more anteriorly $(45.59 \%)$ than in S. runtonensis $(25 \%)$. In the latter species it is situated behind the tip of the $\mathrm{m} 1$ protoconid in 45 of 60 (in $75 \%$ ) and in S. subaraneus only in $54.41 \%$ of specimens. Moreover, the shape of the interarticular area of the condyloid process is always trapezoidal with a rather long lower facet while in $S$. runtonensis this area is rectangular and the lower facet is short (Figure 2.58, 9-12).

\section{DISCUSSION}

Sorex subaraneus described from the Middle Pleistocene of Germany was later found in many European countries (Rzebik-Kowalska, 1998). Its oldest remains were mentioned from the early Early Pleistocene (originally MN17) of Montoussé 5 (France, Clot et al., 1976). It is very probable, however, that the remains referred to undetermined members of the Sorex araneus group [e.g., specimens from the Early Pliocene (MN15) of Ivanovce (the Czech Republic, Rzebik-Kowalska, 1998)] also represent $S$. subaraneus. Except for the Polish localities mentioned above, the species was also collected in the Early Pleistocene localities of Germany and Hungary as well as in the Middle Pleistocene of Bulgaria, the Czech Republic, France, Germany, Hungary and Romania (RzebikKowalska, 1998). The youngest (Late Pleistocene) remains of this species were noted by Jammot (1977) from the Combe Grenal (France) and as S. cf. subaraneus from Trou Jadot Cave (Belgium, Cordy and Toussaint, 1993). Unfortunately, only in a few papers (e.g., in Popov, 1988, 1989 from Bulgaria) descriptions and measurements were presented.

A comparison of dimensions of Sorex subaraneus from the typical and other, especially Polish, populations shows that the first is somewhat larger (Table 1). However, all studied populations of $S$. subaraneus overlap, and their maximal dimensions are usually identical or close to the average dimensions of the fossil and recent $S$. araneus. Our results show that $S$. subaraneus is on average statistically smaller than $S$. araneus (Tables 1, 5 and Appendicex 2, Tables 1-3, 5-6). Its dimensions differ in the same degree from the dimensions of the oldest late Middle Pleistocene Polish population of $S$. araneus as well as from the Late Pleistocene, Early Holocene and recent $S$. araneus from the same area. 
The dimensional study of the fossil Sorex araneus from Poland shows no size differences between populations coming from the oldest, late Middle Pleistocene locality (Nietoperzowa Cave Is. 15-14) and the younger Polish populations from the Late Pleistocene and the Holocene. There are also no size differences between fossil and recent specimens of $S$. araneus in Poland (Table 5).

Contrary to Sorex araneus, the size of S. runtonensis (often compared to or identified with $S$. subaraneus) has slightly increased with geological age. Table 4 shows that the specimens from the Early/Middle Pleistocene of Kozi Grzbiet are on average little smaller than those from caves dated to the Late Pleistocene. For example, the $L$ of $a 1$ in the oldest Middle Pleistocene and in the Late Pleistocene populations does not overlap (although there are only 4 specimens in each group Table 2).

In conclusion, we can say that other studies (e.g., Popov, 1988, 1989, 2003), which take into account the different measurement combinations of the mandible and teeth consistently show that Sorex subaraneus is smaller than $S$. araneus and its dentition is larger than the dentition of $S$. runtonensis (teeth are more massive).

In this study, we point out additional morphological differences between these species. Sorex runtonensis is characterized by more anterior position of the a1, more gracile teeth and coronoid process, as well as more rectangular interarticular area of the condyloid process than S. subaraneus. Despite individual variability, S. runtonensis can be easily distinguished from $S$. subaraneus and $S$. araneus. Therefore, the suggestion of Rofes et al. (2016) on the unity of the S. subaraneus and $S$. runtonensis does not seem justifiable.

According to Zaitsev and Baryshnikov (2002), Sorex satunini does not practically differ in size and morphology from S. subaraneus. Slight differences between these two taxa concern the morphology of a1. This tooth seems to be more robust in $S$. satun$i n i$, its length is only slightly less than that of $p 4$ and it does not have an additional small cusp. Moreover, the internal temporal fossa of $S$. satunini is triangular, rather high and deprived of a bar.

That is why Zaitsev and Baryshnikov (2002) thought that the extant and fossil (Middle Pleistocene) Caucasian Sorex satunini and European fossil $S$. subaraneus should probably be synonimized [the name "satunini" (1922) having the priority above "subaraneus" (1958)]. As the Caucasian shrew belongs to the Sorex araneus group, it could be an ancestor of $S$. araneus which arrived to Europe from Asia.
However, a recent study by Borisov and Orlov (2012) comparing the G-banded karyotypes of Sorex satunini and $S$. araneus revealed major chromosomal rearrangements $(S$. satunini has a more rearranged karyotype than the species of the $S$. araneus group in Western Europe) what implied their evolutionary divergence. According to these authors, the number of chromosome rearrangements shared by the species of the Sorex "araneus" group suggests an Early Pleistocene common ancestor. According to Osipova (2006), S. satunini is most probably an endemic of the Caucasus Mountains.

In the light of data above and morphological features indicated by Zaitsev and Baryshnikov (2002) for S. satunini, S. subaraneus differs from $S$. runtonensis, $S$. araneus and $S$. satunini and it seems to be a valid species. Because of its substantial morphological variability Jammot (1977) is of the opinion that it was the ancestral form not only of the extant $S$. araneus but also of Sorex coronatus. Although $S$. coronatus is very similar to $S$. araneus, its karyotype is quite different (Hausser et al., 1985; Searle and Wójcik, 1998).

According to Jammot (1977), the population of S. subaraneus from the Middle Pleistocene of La Fage (France) is more similar to $S$. coronatus than to $S$. araneus. The karyological studies of Hauser et al. (1985) indicated that $S$. coronatus arose in southern Europe (France) which supports Jammot's (1977) opinion. The Late Pleistocene remains of this species ( $S$. coronatus) were mentioned from Germany (Thomassen, 1996) but their taxonomic status is uncertain. More material is needed to confirm Jammot's (1977) and Hauser's et al. (1985) theory.

As Sorex araneus is concerned, paleontological data show that its oldest remains in Europe come from the Early Pleistocene, while remains identified as S. cf. araneus even from the Late Pliocene (MN16). The species was also found in the Middle and Late Pleistocene localities throughout most of Europe. On the other hand, the oldest remains of $S$. subaraneus are known from the early Early Pleistocene or even earlier. In other words, the ancestor (S. subaraneus) and its descendant (S. araneus) lived in Europe together from at least the Early to the Late Pleistocene. If the identification of the fossil material is accurate and it is correctly dated, then $S$. subaraneus is an unlikely ancestor of $S$. araneus and more probably an ancestor of $S$. coronatus. 


\section{CONCLUSIONS}

1) According to the data cited above $S$. subaraneus should be considered a valid species. It differs in size and morphology from species often compared to or identified with it, such as S. runtonensis, S. satunini and $S$. araneus. In Europe, it lived together with $S$. runtonensis and S. araneus.

2) Sorex araneus did not increase in size with geological age and it inhabited Europe together with $S$. subaraneus. The latter species is on average smaller than $S$. araneus and this difference is constant when material from the Middle Pleistocene, Late Pleistocene, Holocene and recent is compared. They probably share a common ancestor.

3) Sorex runtonensis is also considered a valid species. It slightly increased in size with geological time. In spite of conspicuous individual variation, it can be distinguished from $S$. subaraneus. For now, however, it is not possible to conclude that together with $S$. tundrensis they form one species.

4) It is very probable that specimens of Sorex subaraneus and S. araneus, as well as of S. coronatus, have been confused in the fossil shrew material. In this situation, it is difficult to estimate the timing and direction of dispersal of $S$. subaraneus and $S$. araneus to the European continent, especially since there is practically no data on the fossils of these species from Asia. Studies of all fossil European material belonging to the Sorex "araneus" group as well as new material from the Russian Plain could solve the question of the origin of the forms discussed above.

\section{ACKNOWLEDGEMENTS}

Thanks to the kindness of $M$. Heinze from Erlangen University (place of collection) and L. Maul from Senckenberg Research Institute in Weimar (who took specimen photos), we had the opportunity to study the typical specimens of Sorex subaraneus. We are also grateful to the referees for their insightful comments that improved the manuscript. The study was supported by grant no. 2016/20/S/ST10 from National Science Center of Poland.

\section{REFERENCES}

Borisov, Y.M. and Orlov, V. N. 2012. A comparison of the chromosome G-banding pattern in two Sorex species, S. satunini and S. araneus (Mammalia, Insectivora). Comparative Cytogenetics, 6:267-271. https://doi.org/10.3897/compcytogen.v6i3.3019

Brünner, H., Lugon-Moulin, N., Balloux, F., Fumagalli, L., and Hauser, J. 2002. A taxonomical reevaluation of the Valais chromosome race of the common shrews Sorex araneus (Insectivora: Soricidae). Acta Theriologica, 47:245-275. https://doi.org/10.1007/BF03194146

Clot, J., Chaline, J., Jammot, D., Mourer-Chauviré, C., and Rage, J.C. 1976. Les poches ossifères du Pléistocène moyen et inférieur de Montoussé (Hautes-Pyrénées). Bulletin de la Société d'Histoire Naturelle de Toulouse, 112:146-161.

Cordy, J.-M. and Toussaint, M. 1993. Bio- et chronostratigraphie des dépôts du Trou Jadot à partir des Micromammifères, p. 39-53. In Toussaint, M., Becker, A., Burhenne, M., Cordy, J.M., Gilot, É., Heim, J., and Juvigné, É. (eds.), Le Trou Jadot à Comblain-au-Pont (Province de Liège, Belgique) Paléoécologie et archéologie d'un site du Paléolithique supérieur récent. Étude et Recherches Archéologiques de l'Université de Liège, 58.

Fischer, G. 1814. Zoognosia Tabulis Synopticis Illustrate, 3, Nicolai Sergeidis Vsevolozsky, Moscow.

Hammer, Ø., Harper, D.A.T., and Ryan, P.D. 2001. PAST: Paleontological Statistics Software Package for education and data analysis. Paleontologia Electronica, 4:1-9. https://palaeo-electronica.org/content/1-2-computer-simulation

Harrison, D.L. 1996. Systematic status of Kennard's shrew (Sorex kennardi Hinton, 1911, Insectivora, Soricidae): a study based on British and Polish material. Acta Zoologica Cracoviensia, 39:201-212.

Hausser, J., Catzeflis, F., Meylan, A., and Vogel, P. 1985. Speciation in the Sorex araneus complex (Mammalia: Insectivora). Acta Zoologica Fennica, 170:125-130.

Heller, F. 1930. Eine Forest-Bed-Fauna aus der Sackdillinger Höhle (Oberpfalz). Neues Jahrbuch für Mineralogie, Geologie und Paläontologie. Beilagebände Abteilung, B 63:247298. 
Heller, F. 1958. Eine neue altquartäre Wirbeltierfauna von Erpfingen (Schwäbische Alb). Neues Jahrbuch für Geologie und Paläontologie. Abhandlungen,107:1-102.

Hinton, M.A.C. 1911. The British fossil shrews. Geological Magazine, 8:529-539.

Jammot, D. 1977. Les musaraignes (Soricidae-Insectivora) du Plio-Pléistocène d'Europe. Unpublished PhD Thesis, University of Dijon, Dijon, France.

Kormos, T. 1934. Neue Insektenfresser, Fledermäuse und Nager aus dem Oberpliozän der Villanyer Gegend. Földtani Közlöny, 64:296-321.

Lapini, L. and Testone, R. 1998. A new Sorex from north-eastern Italy (Mammalia, Insectivora: Soricidae). Gortania-Atti del Museo Friulano di Storia Naturale, 20:231-250. (In Italian)

Linnaeus, C. 1758. Systema naturae pre regna tria naturae, secundum classes, ordines, genera, species, cum characteribus, differentiis, synonymis, locis. (Editio decima, reformata). Laurentius Salvus, Stockholm.

Merriam, C.H. 1900. Description of twenty-six new mammals from Alaska and British North America. Proceedings of the Washington Academy of Sciences, 2:13-30.

Millet, P.-A. 1828. Faune de Maine-et-Loire ou description méthodique des Animaux qu'on rencontre dand toute l'étendue du Département de Maine-et-Loire. Rosier, Paris.

Moncunill-Solé, B., Jordana, X., and Köhler, M. 2016. How common is gigantism in insular fossil shrews? Examining the "Island Rule" in soricids (Mammalia: Soricomorpha) from Mediterranean Islands using new body mass estimation models. Zoological Journal of the Linnean Society, 178:163-182. https://doi.org/10.1111/zoj.12399

Novacek, M.J. 1986. The skull of leptictid insectivorans and the higher-level classification of eutherian mammals. Bulletin of the American Museum of Natural History, 183:1-112.

Ognev, S.I. 1922. Contribution à la classification des mammifères insectivores de la Russie. Annuaire du Musée Zoologique de l'Académie des Sciences de Russie, 22:311-350.

Osipova, V.A. 2006. Istoriya formirovaniya fauny zemleroek (sem. Soricidae) Kavkaza. Unpublished PhD Thesis, Rossiǐskaya Akademiya Nauk, Zoologicheskii Institut, SanktPeterburg, Russia. (In Russian)

Osipova, V.A., Rzebik-Kowalska, B., and Zaitsev, M.V. 2006. Intraspecific variability and phylogenetic relationships of the Pleistocene shrew Sorex runtonensis (Soricidae). Acta Theriologica, 51:129-138. https://doi.org/10.1007/BF03192664

Pavlinov, I.Y. and Rossolimo, O.L. 1987. Sistematika mlekopitayushchikh SSSR. Izdatelstvo Moskovskogo Universiteta, Moscow. (In Russian)

Popov, V.V. 1988. Middle Pleistocene small mammals (Mammalia: Insectivora, Lagomorpha, Rodentia) from Verbeshnitsa (Bulgaria). Acta Zoologica Cracoviensia, 31:193-234.

Popov, V.V. 1989. Middle Pleistocene small mammals (Insectivora, Lagomorpha, Rodentia) from Morovitsa Cave (North Bulgaria). Acta Zoologica Cracoviensia, 32:561-588.

Popov, V.V. 2003. The Pliocene Soricidae (Insectivora, Mammalia) from Varshets (North Bulgaria). Acta Zoologica Cracoviensia, 46: 43-72.

Prost, S., Klietmann, J., van Kolfschoten, T., Guralnick, R., Waltari, E., Vrieling, K., Stiller, M., Nagel, D., Rabeder, G., Hofreiter, M., and Sommer, R. 2013. Effects of Late Quaternary climate change on Palearctic shrews. Global Change Biology, 19:1865-1874.

Qiu, Z.D. and Storch, G. 2005. China, p. 37-50. In van den Hoek Ostende, L.W., Doukas, C.S., and Reumer, J.W.F. (eds.), The Fossil Record of the Eurasian Neogene Insectivores (Erinaceomorpha, Soricomorpha, Mammalia). Scripta Geologica Special Issue 5, The Netherlands National Museum of Geology and Mineralogy, Leiden.

Reumer, J.W.F. 1984. Ruscinian and Early Pleistocene Soricidae (Insectivora, Mammalia) from Tegelen (The Netherlands) and Hungary. Scripta Geologica, 73:1-173.

Rofes, J., Moya-Costa, R., Bennàsar, M., Blain, H.A., and Cuenca-Bescós, G. 2016. Biostratigraphy, palaeogeography and palaeoenvironmental significance of Sorex runtonensis Hinton, 1911 (Mammalia, Soricidae): First record from the Iberian Peninsula. Palaeogeography, Palaeoclimatology, Palaeoecology, 459:508-517. https://doi.org/10.1016/ j.palaeo.2016.07.021

Rzebik-Kowalska, B. 1991. Pliocene and Pleistocene Insectivora (Mammalia) of Poland. VIII. Soricidae: Sorex Linnaeus 1758, Neomys Kaup, 1829, Macroneomys Fejfar, 1966, Paenelimnoecus Baudelot, 1972 and Soricidae indeterminata. Acta zOologica Cracoviensia, 34:323-424.

Rzebik-Kowalska, B. 1998. Fossil history of shrews in Europe, p. 23-92. In Wójcik, J.M. and Wolsan, M. (eds.), Evolution of Shrews. Mammal Research Institute, Polish Academy of Sciences, Białowieża. 
Rzebik-Kowalska, B. 2000. Insectivora (Mammalia) from the Early and early Middle Pleistocene of Betfia in Romania. I. Soricidae Fishervon Waldheim, 1817. Acta Zoological Cracoviensia, 43:1-53.

Rzebik-Kowalska, B. 2013. Sorex bifidus n. sp. and the rich insectivore mammal fauna (Erinaceomorpha, Soricimorpha, Mammalia) from the Early Pleistocene Żabia Cave in Poland. Palaeontologia Electronica 16.2.12A: 1-35. https://doi.org/10.26879/376

Searle, J.B. and Wójcik, J.M. 1998. Chromosomal evolution: The Case of Sorex araneus, p. 219268. In Wójcik, J.M. and Wolsan, M. (eds.), Evolution of Shrews. Mammal Research Institute, Polish Academy of Sciences, Białowieża.

Storch, G., Qiu, Zh., and Zazhigin, V.S. 1998. Fossil history of shrews in Asia, p. 92-117. In Wójcik, J.M., and Wolsan, M. (eds.), Evolution of Shrews. Mammal Research Institute, Polish Academy of Sciences, Białowieża.

Thomassen, H. 1996. De Midden Paleolitische kleine zoogdierfauna uit de Sesselfels-grot (ZuidDuitsland), met nadruk op de spitsmuizen (Mammalia, Insectivora, Soricidae). Cranium, 13:47-52.

Van der Meulen, A.J. 1973. Middle Pleistocene smaller mammals from the Monte Peglia (Orvieto, Italy), with special reference to the phylogeny of Microtus (Arvicolidae, Rodentia). Quaternaria, 17:1-144.

Waddell, P.J., Okada, N., and Hasegawa, M. 1999. Towards resolving the interordinal relationships of placental mammals. Systematic Biology, 48:1-5. https://doi.org/10.1093/ sysbio/48.1.1

Wolsan, M. and Hutterer, R. 1998. A list of the living species of shrews, p. 425-448. In Wójcik, J.M. and Wolsan, M. (eds.), Evolution of Shrews. Mammal Research Institute, Polish Academy of Sciences, Białowieża.

Yudin, B.S. 1989. Insectivore Mammals of Siberia. Nauka, Novosibirsk. (In Russian)

Zaitsev, M.V. and Baryshnikov, G.F. 2002. Pleistocene Soricidae (Lipotyphla, Insectivora, Mammalia) from Treugolnaya Cave, Northern Caucasus, Russia. Acta Zoologica Cracoviensia, 45:83-305.

Zhang, S., Wang, Ch., Li, Y., Cuy, D., You, Y., Han, D., Ye, X., Hou, L., Zheng, S.H., Yu, Q., Wang, P., Xia, Y., and Chen, W. 1993.Comprehensive study on the Jinniusham Paleolithic site. Memoirs of the Institute of Vertebrata Palaeontology and Palaeoanthropology, Academia Sinica 19:1-164. (In Chinese) 


\section{APPENDIX 1}

List of specimens of Sorex subaraneus, S. araneus and S. runtonensis.

S. subaraneus - typical collection from Erpfingen - (nos. coll. Heller 1938/a1-a12 and b1b6).

S. subaraneus from Kadzielnia 1 - numbers: MF/1958, Przymiłowice 3A - MF/6864, Kozi

Grzbiet - MF/1957, Rębielice Królewskie 4 - MF/1962.

$S$. araneus recent - numbers: $M / 2, M / 59, M / 71, M / 4518$, $\mathrm{M} / 4557, \mathrm{M} / 4561, \mathrm{M} / 4573, \mathrm{M} / 4674$,

$\mathrm{M} / 4707, \mathrm{M} / 4743, \mathrm{M} / 8580, \mathrm{M} / 8582-83, \mathrm{M} / 8585$ - 92, M/ 8595-97, M/8599 a, b, c, M/10303, M/11027, M/ 11030, M/11290-93, M/11296-97, M/11299, M/ 11300-301, M/11303, M/11305308, M/11310-311, M/ 11314-317.

Sorex araneus from: Nietoperzowa Cave (Is. 15-14) MF/874, Puchacza Skała Cave III -

MF/937, Borsuka Cave - MF/6870, Raj Cave (Is. 1-11) MF/6871, Obłazowa Cave 2 MF/6872, Krucza Skała
Rock Shelter (Is. 1-8 and I-V) - MF/3193, Koziarnia Cave (Is. 3-19)

- MF/898, Nietoperzowa Cave (Is. 8-9,13) - MF/874, Żytnia Skała Cave 1 and $2-\mathrm{MN} / 927$,

Mamutowa Cave 1 and 2 - MF/6873, Komarowa Cave (I. Ftx) - MF/3185, Obłazowa Cave -

MF/5104, Józefów - MF/629, Nad Mosurem Starym Duża Cave - MF/6875, Duża Cave at Mączna Skała (l. 3) $-\mathrm{MF} / 4249$.

Sorex runtonensis from: Żabia Cave - ZPAL M. 12/6, Kozi Grzbiet - MF/1961, Raj Cave (I. 1-10) - MF/ 6876, Krucza Skała

Rock Shelter (Is. 1-8, I-V) - MF/3192, Komarowa Cave (remaining layers) MF/3184, Obłazowa Cave - F/ 2261. 


\section{APPENDIX 2}

APPENDIX 2 TABLE 1. Dimensions (in mm) of mandible and lower teeth of Sorex subaraneus from several localities in Europe.

\begin{tabular}{|c|c|c|c|c|c|c|c|c|c|c|}
\hline & \multicolumn{2}{|c|}{ Sorex cf. subaraneus } & \multicolumn{2}{|c|}{ Sorex subaraneus } & \multicolumn{2}{|c|}{ Sorex subaraneus } & \multirow{2}{*}{\multicolumn{2}{|c|}{$\begin{array}{c}\text { Sorex subaraneus } \\
\text { Kadzielnia 1, } \\
\text { Przymiłowice 3A, } \\
\text { Kozi Grzbiet, } \\
\text { Rębielice } \\
\text { Królewskie 4, Early } \\
\text { and Middle } \\
\text { Pleistocene } \\
\text { Poland }\end{array}$}} & \multirow{2}{*}{\multicolumn{2}{|c|}{$\begin{array}{c}\text { Sorex subaraneus } \\
\\
\text { Erpfingen } \\
\text { Middle Pleistocene } \\
\text { Germany }\end{array}$}} \\
\hline & \multicolumn{2}{|c|}{$\begin{array}{c}\text { Betfia XIII, IX, VII/3, VIII } \\
\text { 4, V (Rzebik- } \\
\text { Kowalska, 2000) } \\
\text { Early Pleistocene } \\
\text { Romania }\end{array}$} & \multicolumn{2}{|c|}{$\begin{array}{c}\text { Morovitsa Cave } \\
\text { (Popov, 1989) } \\
\text { Middle Pleistocene } \\
\text { Bulgaria }\end{array}$} & \multicolumn{2}{|c|}{$\begin{array}{c}\text { Varbeshnitsa } \\
\text { (Popov, 1988) } \\
\text { Middle Pleistocene } \\
\text { Bulgaria }\end{array}$} & & & & \\
\hline & Min. - Max. & $\mathbf{N}$ & Min. - Max. & $\mathbf{N}$ & Min. - Max. & $\mathbf{N}$ & Min. - Max. & $\mathbf{N}$ & Min. - Max. & $\mathbf{N}$ \\
\hline $\begin{array}{l}\mathrm{m} 1 \mathrm{~L} \\
\mathrm{~m} 1 \mathrm{~W}\end{array}$ & $\begin{array}{l}1.31-1.48 \\
0.81-0.88\end{array}$ & $\begin{array}{l}6 \\
5\end{array}$ & - & - & $\begin{array}{c}1.32-1.45 \\
-\end{array}$ & $\begin{array}{l}8 \\
-\end{array}$ & $\begin{array}{l}1.35-1.49 \\
0.80-0.98\end{array}$ & $\begin{array}{l}61 \\
60\end{array}$ & $\begin{array}{l}1.41-1.66 \\
0.82-0.93\end{array}$ & $\begin{array}{l}7 \\
7\end{array}$ \\
\hline $\begin{array}{l}\mathrm{m} 2 \mathrm{~L} \\
\mathrm{~m} 2 \mathrm{~W}\end{array}$ & $\begin{array}{l}1.15-1.28 \\
0.76-0.97\end{array}$ & $\begin{array}{l}4 \\
3\end{array}$ & - & - & $\begin{array}{c}1.17-1.34 \\
-\end{array}$ & $\begin{array}{l}12 \\
-\end{array}$ & $\begin{array}{l}1.18-1.30 \\
0.73-0.87\end{array}$ & $\begin{array}{l}46 \\
45\end{array}$ & $\begin{array}{l}1.25-1.40 \\
0.75-0.86\end{array}$ & $\begin{array}{l}5 \\
5\end{array}$ \\
\hline $\begin{array}{l}\mathrm{m} 3 \mathrm{~L} \\
\mathrm{~m} 3 \mathrm{~W}\end{array}$ & $\begin{array}{l}1.06 \\
0.65\end{array}$ & $\begin{array}{l}1 \\
1\end{array}$ & - & - & $\begin{array}{c}0.97-1.10 \\
-\end{array}$ & $\begin{array}{l}6 \\
-\end{array}$ & $\begin{array}{l}0.95-1.11 \\
0.56-0.67\end{array}$ & $\begin{array}{l}27 \\
27\end{array}$ & $\begin{array}{l}0.99-1.13 \\
0.64-0.78\end{array}$ & $\begin{array}{l}4 \\
4\end{array}$ \\
\hline m1-m3 L & - & - & $3.57-3.95$ & 4 & $3.52-3.55$ & 2 & $3.57-3.78$ & 16 & $3.52-3.80$ & 4 \\
\hline $\begin{array}{l}\mathrm{H} \text { of } \\
\text { ascending } \\
\text { ramus }\end{array}$ & $3.95-4.09$ & 4 & $4.09-4.52$ & 7 & $4.12-4.37$ & 10 & $3.80-4.54$ & 18 & $4.01-4.64$ & 18 \\
\hline $\begin{array}{l}\text { W of coronoid } \\
\text { process }\end{array}$ & $0.76-0.86$ & 4 & - & - & - & - & $0.70-1.00$ & 19 & - & - \\
\hline $\begin{array}{l}\mathrm{H} \text { of condyloid } \\
\text { process }\end{array}$ & $1.60-1.78$ & 2 & - & - & $1.30-1.50$ & 11 & $1.57-1.87$ & 5 & $1.44-1.84$ & 17 \\
\hline
\end{tabular}


APPENDIX 2 TABLE 2. Dimension (in $\mathrm{mm}$ ) of mandible and lower teeth of Sorex subaraneus from four localities in Poland.

\begin{tabular}{|c|c|c|c|c|c|c|c|c|c|c|c|c|c|c|c|c|c|c|}
\hline & \multicolumn{18}{|c|}{ Sorex subaraneus } \\
\hline & \multicolumn{4}{|c|}{$\begin{array}{c}\text { Kadzielnia } 1 \\
\text { Early Pleistocene }\end{array}$} & \multicolumn{5}{|c|}{$\begin{array}{l}\text { Przymiłowice 3A } \\
\text { Early Pleistocene }\end{array}$} & \multicolumn{5}{|c|}{$\begin{array}{c}\text { Kozi Grzbiet } \\
\text { Early/Middle Pleistocene }\end{array}$} & \multicolumn{4}{|c|}{$\begin{array}{c}\text { Rębielice Królewskie } 4 \\
\text { Middle Pleistocene }\end{array}$} \\
\hline & Min. & $\mathbf{X}$ & Max. & $\mathbf{N}$ & Min. & $\mathbf{X}$ & Max. & $\mathbf{N}$ & Min. & $\mathbf{X}$ & Max. & $\mathbf{N}$ & sd & cv & Min. & $\mathbf{X}$ & Max. & $\mathbf{N}$ \\
\hline i1 L & - & - & - & - & - & 3.60 & - & 1 & 3.37 & 3.52 & 3.66 & 17 & 0.10 & 2.84 & - & - & - & - \\
\hline i1 H & - & - & - & - & - & 0.94 & - & 1 & 0.71 & 0.84 & 0.93 & 35 & 0.04 & 4.76 & - & 0.86 & - & 1 \\
\hline a1 L (bucc) & - & - & - & - & - & 1.05 & - & 1 & 0.82 & 0.94 & 1.05 & 12 & 0.06 & 6.38 & - & 0.95 & - & 1 \\
\hline $\mathrm{p} 4 \mathrm{~L}$ & - & - & - & - & - & 1.13 & - & 1 & 0.89 & 1.02 & 1.14 & 33 & 0.05 & 4.90 & - & - & - & - \\
\hline p4 W & - & - & - & - & - & 0.80 & - & 1 & 0.65 & 0.72 & 0.80 & 31 & 0.04 & 5.56 & - & - & - & - \\
\hline m1 L & 1.45 & 1.46 & 1.47 & 2 & - & - & - & - & 1.35 & 1.43 & 1.49 & 56 & 0.03 & 3.00 & 1.44 & 1.45 & 1.46 & 2 \\
\hline $\mathrm{m} 1 \mathrm{~W}$ & 0.86 & 0.88 & 0.90 & 2 & - & - & - & - & 0.80 & 0.85 & 0.98 & 57 & 0.03 & 3.53 & 0.85 & 0.86 & 0.88 & 2 \\
\hline m2 L & 1.27 & 1.28 & 1.29 & 2 & - & - & - & - & 1.18 & 1.25 & 1.30 & 40 & 0.03 & 2.40 & 1.24 & 1.26 & 1.28 & 4 \\
\hline $\mathrm{m} 2 \mathrm{~W}$ & 0.80 & 0.83 & 0.86 & 2 & - & - & - & - & 0.73 & 0.78 & 0.87 & 39 & 0.03 & 3.85 & 0.76 & 0.76 & 0.77 & 4 \\
\hline m3 L & 1.00 & 1.00 & 1.01 & 2 & - & - & - & - & 0.95 & 1.04 & 1.11 & 24 & 0.04 & 3.85 & - & 1.00 & - & 1 \\
\hline m3 W & 0.65 & 1.65 & 0.66 & 2 & - & - & - & - & 0.56 & 0.62 & 0.67 & 24 & 0.03 & 4.84 & - & 0.59 & - & 1 \\
\hline $\mathrm{m} 1-\mathrm{m} 3 \mathrm{~L}$ & - & 3.70 & - & 1 & - & - & - & - & 3.57 & 3.69 & 3.95 & 16 & 0.10 & 2.71 & - & - & - & - \\
\hline $\begin{array}{l}\mathrm{H} \text { of } \\
\text { mandible } \\
\text { below m2 }\end{array}$ & 1.24 & 1.28 & 1.30 & 3 & - & - & - & - & 1.12 & 1.23 & 1.33 & 43 & 0.05 & 4.06 & 1.19 & 1.24 & 1.30 & 2.00 \\
\hline $\begin{array}{l}\mathrm{H} \text { of } \\
\text { ascending } \\
\text { ramus }\end{array}$ & 4.40 & 4.40 & 4.41 & 2 & - & - & - & - & 3.80 & 4.18 & 4.54 & 16 & 0.19 & 4.54 & - & - & - & - \\
\hline $\begin{array}{l}\text { W of } \\
\text { coronoid } \\
\text { process }\end{array}$ & 0.94 & 0.95 & 0.96 & 2 & - & - & - & - & 0.70 & 0.87 & 1.00 & 17 & 0.07 & 8.05 & - & - & - & - \\
\hline $\begin{array}{l}\text { H of } \\
\text { condyloid } \\
\text { process }\end{array}$ & - & - & - & - & - & - & - & - & 1.57 & 1.72 & 1.87 & 5 & - & - & - & - & - & - \\
\hline $\begin{array}{l}\text { W of } \\
\text { interarticular } \\
\text { area }\end{array}$ & - & - & - & - & - & - & - & - & 0.5 & 0.57 & 0.66 & 12 & 0.05 & 8.77 & - & - & - & - \\
\hline
\end{tabular}


APPENDIX 2 TABLE 3. Dimensions (in mm) of upper teeth of Sorex subaraneus in Poland.

\begin{tabular}{|c|c|c|c|c|c|c|c|c|c|c|}
\hline & \multicolumn{10}{|c|}{ Sorex subaraneus } \\
\hline & \multicolumn{6}{|c|}{$\begin{array}{c}\text { Kozi Grzbiet } \\
\text { Early/Middle Pleistocene }\end{array}$} & \multicolumn{4}{|c|}{$\begin{array}{l}\text { Rębielice Królewskie 1A } \\
\text { Middle Pleistocene }\end{array}$} \\
\hline & Min. & $\mathbf{X}$ & Max. & $\mathbf{N}$ & sd & cv & Min. & $\mathbf{X}$ & Max. & $\mathbf{N}$ \\
\hline I1 L & - & - & - & - & - & - & - & - & - & - \\
\hline I1 $\mathrm{L}$ of talon & - & - & - & - & - & - & - & - & - & - \\
\hline $11 \mathrm{H}$ of talon & - & 1.09 & - & 1 & - & - & - & - & - & - \\
\hline A1 L & 0.76 & 0.81 & 0.86 & 2 & - & - & - & - & - & - \\
\hline A1 W & 0.72 & 0.78 & 0.85 & 2 & - & - & - & - & - & - \\
\hline A2 L & 0.72 & 0.78 & 0.86 & 2 & - & - & - & - & - & - \\
\hline A2 W & 0.70 & 0.76 & 0.83 & 2 & - & - & - & - & - & - \\
\hline A3 L & 0.62 & 0.65 & 0.69 & 2 & - & - & - & - & - & - \\
\hline A3 W & 0.61 & 0.66 & 0.71 & 2 & - & - & - & - & - & - \\
\hline A4 L & - & 0.64 & - & 1 & - & - & - & 0.57 & - & 1 \\
\hline A4 W & - & 0.64 & - & 1 & - & - & - & 0.59 & - & 1 \\
\hline A5 L & 0.48 & 0.51 & 0.54 & 2 & - & - & - & $0.43^{*}$ & - & 1 \\
\hline A5 W & 0.59 & 0.60 & 0.61 & 2 & - & - & - & 0.58 & - & 1 \\
\hline P4 L (bucc.) & 1.44 & 1.50 & 1.56 & 12 & 0.03 & 2 & - & 1.51 & - & 1 \\
\hline M1 L (max.) & 1.31 & 1.39 & 1.46 & 14 & 0.04 & 2.88 & - & - & - & - \\
\hline M1 L (med.) & 1.05 & 1.09 & 1.18 & 14 & 0.04 & 3.67 & - & - & - & - \\
\hline M1 W (max.) & 1.47 & 1.55 & 1.61 & 14 & 0.04 & 2.58 & - & - & - & - \\
\hline M2 L (max.) & 1.21 & 1.26 & 1.33 & 7 & 0.05 & 3.97 & - & - & - & - \\
\hline M2 L (med.) & 0.96 & 1.02 & 1.06 & 8 & 0.03 & 2.94 & - & - & - & - \\
\hline M2 W (max.) & 1.40 & 1.46 & 1.50 & 7 & 0.04 & 2.74 & - & - & - & - \\
\hline
\end{tabular}


APPENDIX 2 TABLE 4. Comparison of dimensions (in $\mathrm{mm}$ ) of upper teeth of Sorex subaraneus and Sorex runtonensis in Poland.

\begin{tabular}{|c|c|c|c|c|c|c|c|c|c|c|c|c|c|c|c|c|c|c|}
\hline & & & \multicolumn{10}{|c|}{ Sorex runtonensis } & \multicolumn{6}{|c|}{ Sorex subaraneus } \\
\hline & \multicolumn{6}{|c|}{$\begin{array}{c}\text { Żabia Cave, Early Pleistocene, } \\
\text { Rzebik-Kowalska, } 2013\end{array}$} & \multicolumn{6}{|c|}{$\begin{array}{l}\text { Raj Cave, Late Pleistocene, } \\
\text { Vistulian } \\
\text { Krucza Skała Rock Shelter, Late } \\
\text { Pleistocene, Late Vistulian }\end{array}$} & \multicolumn{6}{|c|}{$\begin{array}{c}\text { Komarowa Cave, Late Pleistocene - } \\
\text { Holocene } \\
\text { Kozi Grzbiet, Early/Middle } \\
\text { Pleistocene }\end{array}$} \\
\hline & Min. & $\mathbf{X}$ & Max. & $\mathbf{N}$ & sd & cv & Min. & $\mathbf{X}$ & Max. & $\mathbf{N}$ & sd & cv & Min. & $\mathbf{X}$ & Max. & $\mathbf{N}$ & sd & cv \\
\hline A3 L & - & 0.67 & - & 1 & - & - & - & 0.63 & - & 1 & - & - & 0.62 & 0.65 & 0.69 & 2 & - & - \\
\hline A3 W & - & 0.63 & - & 1 & - & - & - & 0.66 & - & 1 & - & - & 0.61 & 0.66 & 0.71 & 2 & - & - \\
\hline A4 L & 0.49 & 0.52 & 0.55 & 2 & - & - & 0.50 & 0.51 & 0.52 & 3 & - & - & - & 0.64 & - & 1 & - & - \\
\hline A4 W & 0.56 & 0.58 & 0.60 & 2 & - & - & 0.58 & 0.60 & 0.62 & 3 & - & - & - & 0.64 & - & 1 & - & - \\
\hline A5 L & 0.48 & 0.48 & 0.49 & 3 & - & - & 0.48 & 0.53 & 0.56 & 3 & - & - & 0.48 & 0.51 & 0.54 & 2 & - & - \\
\hline A5 W & 0.49 & 0.53 & 0.56 & 3 & - & - & 0.55 & 0.57 & 0.60 & 3 & - & - & 0.59 & 0.60 & 0.61 & 2 & - & - \\
\hline $\begin{array}{l}\mathrm{P} 4 \mathrm{~L} \\
\text { (bucc.) }\end{array}$ & 1.30 & 1.42 & 1.55 & 16 & 0.77 & 4.93 & 1.30 & 1.42 & 1.51 & 9 & 0.07 & 4.93 & 1.44 & 1.50 & 1.56 & 12 & 0.03 & 2.00 \\
\hline P4 L & 1.28 & 1.32 & 1.36 & 13 & 0.03 & 2.27 & 1.32 & 1.38 & 1.45 & 9 & 0.04 & 2.90 & 1.31 & 1.39 & 1.46 & 14 & 0.04 & 2.28 \\
\hline (max.) & 1.00 & 1.06 & 1.11 & 14 & 0.03 & 2.83 & 1.04 & 1.12 & 1.16 & 9 & 0.04 & 3.57 & 1.05 & 1.09 & 1.18 & 14 & 0.04 & 3.67 \\
\hline $\begin{array}{l}\text { M1 L } \\
\text { (med.) } \\
\text { M1 W } \\
\text { (max.) }\end{array}$ & 1.43 & 1.51 & 1.63 & 13 & 0.05 & 3.31 & 1.39 & 1.48 & 1.56 & 9 & 0.06 & 4.05 & 1.47 & 1.55 & 1.61 & 14 & 0.04 & 2.58 \\
\hline M2 L & 1.19 & 1.25 & 1.31 & 11 & 0.05 & 4.00 & 1.18 & 1.25 & 1.35 & 8 & 0.06 & 4.80 & 1.21 & 1.26 & 1.33 & 7 & 0.05 & 3.97 \\
\hline (max.) & 0.96 & 1.01 & 1.04 & 11 & 0.03 & 2.97 & 0.95 & 1.01 & 1.05 & 9 & 0.03 & 2.97 & 0.96 & 1.02 & 1.06 & 8 & 0.03 & 2.94 \\
\hline $\begin{array}{l}\text { M2 L } \\
\text { (med.) } \\
\text { M2 W } \\
\text { (max.) }\end{array}$ & 1.35 & 1.43 & $?$ & 11 & 0.04 & 2.80 & 1.30 & 1.41 & 1.51 & 8 & 0.07 & 4.96 & 1.40 & 1.46 & 1.50 & 7 & 0.04 & 2.74 \\
\hline
\end{tabular}


APPENDIX 2 TABLE 5. Dimensions (in mm) of upper teeth of recent Sorex araneus in Poland.

\begin{tabular}{lcccccc}
\hline & \multicolumn{5}{c}{ Sorex araneus } \\
\hline & \multicolumn{5}{c}{ recent } \\
& Min. & $\mathbf{X}$ & Max. & N & sd & cv \\
\hline & 1.58 & 1.76 & 1.94 & 32 & 0.10 & 5.68 \\
\hline I1 L & 0.82 & 0.96 & 1.11 & 45 & 0.07 & 7.29 \\
I1 L of talon & 1.10 & 1.22 & 1.31 & 31 & 0.05 & 4.10 \\
I1 H of talon & 2.66 & 2.86 & 3.15 & 47 & 0.18 & 6.29 \\
A1 - A5 L & 0.79 & 0.87 & 0.96 & 48 & 0.04 & 4.60 \\
A1 L & 0.73 & 0.81 & 0.89 & 48 & 0.03 & 3.70 \\
A1 W & 0.75 & 0.84 & 0.94 & 48 & 0.04 & 4.76 \\
A2 L & 0.71 & 0.77 & 0.81 & 48 & 0.02 & 2.60 \\
A2 W & 0.67 & 0.75 & 0.82 & 49 & 0.04 & 5.33 \\
A3 L & 0.62 & 0.68 & 0.74 & 49 & 0.03 & 4.41 \\
A3 W & 0.52 & 0.62 & 0.72 & 50 & 0.05 & 8.06 \\
A4 L & 0.55 & 0.63 & 0.69 & 50 & 0.03 & 4.76 \\
A4 W & 0.40 & 0.47 & 0.58 & 50 & 0.04 & 8.51 \\
A5 L & 0.47 & 0.56 & 0.66 & 50 & 0.05 & 8.93 \\
A5 W & 1.46 & 1.56 & 1.66 & 51 & 0.04 & 2.56 \\
P4 L & 1.38 & 1.47 & 1.57 & 51 & 0.05 & 3.40 \\
M1 L (max.) & 1.06 & 1.13 & 1.24 & 51 & 0.04 & 3.54 \\
M1 L (med.) & 1.58 & 1.67 & 1.83 & 51 & 0.05 & 2.99 \\
M1 W (max.) & 1.20 & 1.29 & 1.37 & 50 & 0.04 & 3.10 \\
M2 L (max.) & 0.98 & 1.04 & 1.14 & 50 & 0.03 & 2.88 \\
M2 L (med.) & 1.48 & 1.57 & 1.71 & 50 & 0.05 & 3.18 \\
M2 W (max.) & 0.67 & 0.72 & 0.81 & 46 & 0.03 & 4.17 \\
M3 L (max.) & 1.14 & 1.24 & 1.33 & 45 & 0.04 & 3.23 \\
M3 W (max.) & & & & & &
\end{tabular}


APPENDIX 2 TABLE 6. Dimensions (in $\mathrm{mm}$ ) of upper teeth of fossil Sorex araneus in Poland.

\begin{tabular}{|c|c|c|c|c|c|c|c|c|c|c|c|c|}
\hline & \multicolumn{12}{|c|}{ Sorex araneus } \\
\hline & \multicolumn{6}{|c|}{$\begin{array}{c}\text { Puchacza Skała Cave III, Borsuka Cave, Raj Cave } \\
\text { (Is. 1-10), Obłazowa Cave 2, Krucza Skała Rock } \\
\text { Shelter (Is. 1-8 and I-V), Koziarnia Cave (Is. 3-19), } \\
\text { Nietoperzowa Cave (Is. 8-9 and 13), Żytnia Skała } \\
\text { Cave 1, Mamutowa Cave } 1 \text { and } 2 \text { and Komarowa } \\
\text { Cave (I. Ftx) } \\
\text { Late Pleistocene }\end{array}$} & \multicolumn{6}{|c|}{$\begin{array}{c}\text { Józefów, Raj Cave (I. 11), Nad Mosurem Starym } \\
\text { Duża Cave, Duża Cave at Mączna Skała (I. 3), } \\
\text { Żytnia skała Cave } 2 \\
\text { Holocene }\end{array}$} \\
\hline & Min. & $\mathbf{X}$ & Max. & $\mathbf{N}$ & sd & cv & Min. & $\mathbf{X}$ & Max. & $\mathbf{N}$ & sd & cv \\
\hline I1 L & - & - & - & - & - & & 1.75 & 1.83 & 1.92 & 2 & - & - \\
\hline I1 $\mathrm{L}$ of talon & - & - & - & - & - & & 0.91 & 1.04 & 1.14 & 3 & - & - \\
\hline $11 \mathrm{H}$ of talon & - & - & - & - & - & & 1.25 & 1.27 & 1.30 & 2 & - & - \\
\hline A1-A5 L & - & 2.92 & - & 1 & - & - & - & - & - & - & - & - \\
\hline A1 L & 0.84 & 0.86 & 0.90 & 3 & - & - & - & 0.88 & - & 1 & - & - \\
\hline A1 W & 0.86 & 0.90 & 0.94 & 3 & - & - & - & 0.83 & - & 1 & - & - \\
\hline $\mathrm{A} 2 \mathrm{~L}$ & 0.77 & 0.86 & 0.96 & 8 & 0.06 & 6.98 & 0.85 & 0.89 & 0.93 & 4 & - & - \\
\hline A2 W & 0.83 & 0.87 & 0.91 & 8 & 0.03 & 3.45 & 0.80 & 0.86 & 0.91 & 4 & - & - \\
\hline A3 L & 0.63 & 0.78 & 0.86 & 14 & 0.06 & 7.69 & 0.75 & 0.80 & 0.86 & 6 & - & - \\
\hline A3 W & 0.71 & 0.77 & 0.83 & 14 & 0.03 & 3.90 & 0.71 & 0.76 & 0.83 & 7 & 0.04 & 5.26 \\
\hline A4 L & 0.61 & 0.67 & 0.77 & 9 & 0.05 & 7.46 & 0.58 & 0.73 & 0.86 & 5 & - & - \\
\hline A4 W & 0.64 & 0.72 & 0.80 & 9 & 0.05 & 6.94 & 0.70 & 0.77 & 0.87 & 5 & - & - \\
\hline A5 L & 0.48 & 0.56 & 0.66 & 5 & - & - & - & 0.51 & - & 1 & - & - \\
\hline A5 W & 0.61 & 0.67 & 0.71 & 5 & - & - & - & 0.67 & - & 1 & - & - \\
\hline P4 L(bucc.) & 1.40 & 1.58 & 1.76 & 56 & 0.07 & 4.43 & 1.49 & 1.58 & 1.71 & 28 & 0.06 & 3.80 \\
\hline M1 L(max.) & 1.39 & 1.47 & 1.58 & 47 & 0.05 & 3.40 & 1.39 & 1.46 & 1.56 & 22 & 0.05 & 3.42 \\
\hline M1 L(med.) & 1.05 & 1.16 & 1.30 & 47 & 0.06 & 5.17 & 1.06 & 1.13 & 1.22 & 22 & 0.04 & 3.54 \\
\hline M1 W(max.) & 1.46 & 1.62 & 1.80 & 46 & 0.06 & 3.70 & 1.54 & 1.63 & 1.75 & 22 & 0.06 & 3.68 \\
\hline M2 L(max.) & 1.24 & 1.30 & 1.42 & 28 & 0.05 & 3.85 & 1.23 & 1.30 & 1.38 & 13 & 0.07 & 5.38 \\
\hline M2 L(med.) & 0.98 & 1.05 & 1.12 & 30 & 0.04 & 3.81 & 0.99 & 1.05 & 1.14 & 14 & 0.04 & 3.31 \\
\hline M2 W(max.) & 1.39 & 1.53 & 1.63 & 26 & 0.06 & 3.93 & 1.44 & 1.52 & 1.66 & 14 & 0.06 & 3.95 \\
\hline M3 L(max.) & - & 0.70 & - & 1 & - & - & - & 0.68 & - & 1 & - & - \\
\hline M3 W(max.) & - & 1.15 & - & 1 & - & - & - & 1.14 & - & 1 & - & - \\
\hline
\end{tabular}




\section{APPENDIX 3}

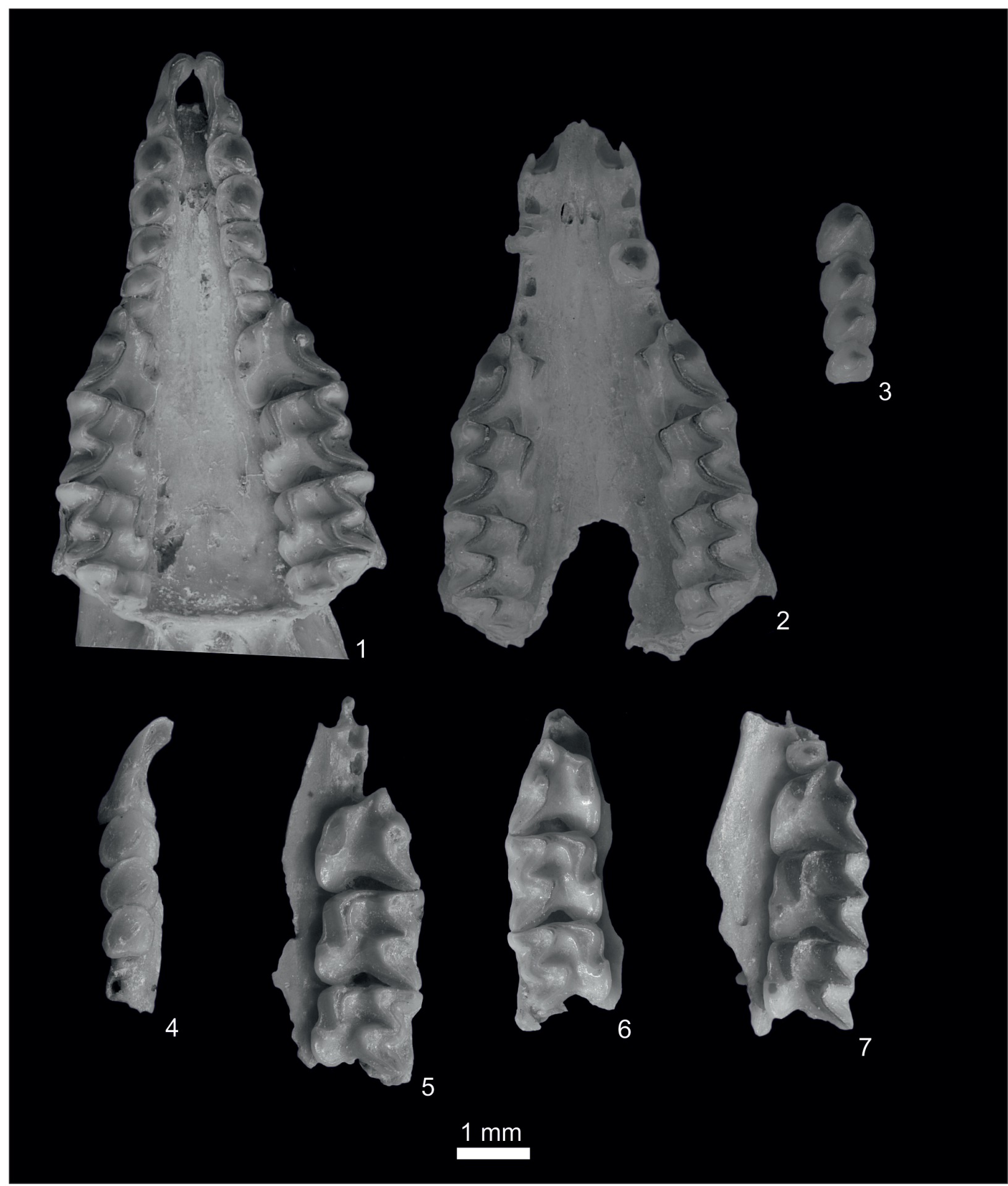

APPENDIX 3 FIGURE 1. 1 - Sorex araneus, recent (no. M/8583). 2-3 -S. araneus, Holocene, Raj Cave, layer 11 (nos. MF/6871/5 and /2) respectively. 4-5 - S. araneus, Late Pleistocene, Raj Cave, L. 4 (nos. 17a-17b), respectively. 6 - S. subaraneus, Early/Middle Pleistocene, Kozi Grzbiet, I. 2C (no. MF/1957/25). 7 - S. runtonensis, Late Pleistocene, Krucza Skała Rock Shelter, I. 8 (no. MF/3192/1). 


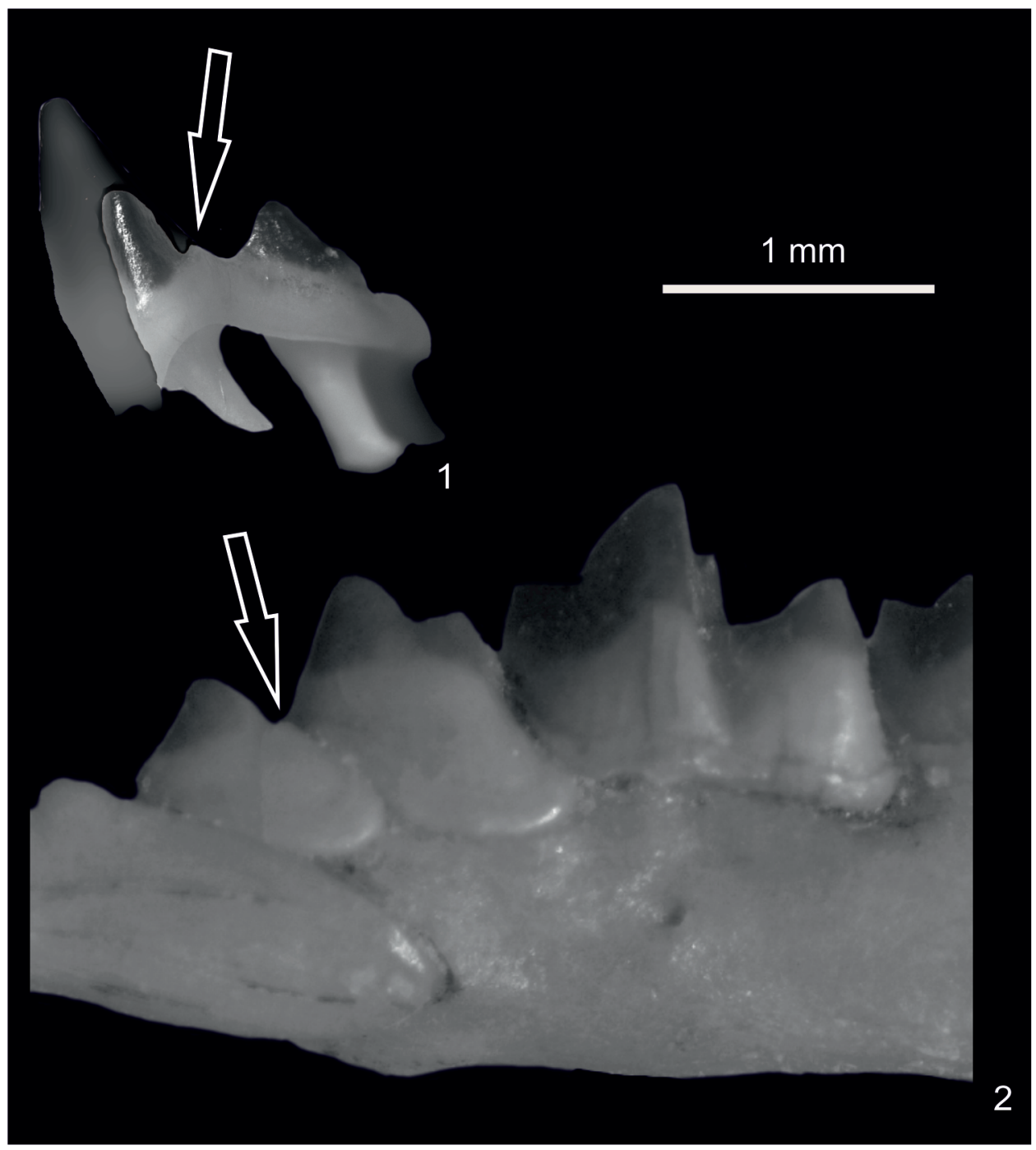

APPENDIX 3 FIGURE 2. 1 - S. araneus, recent, anterior view of left P4 (no. M/10303) and 2 - S. subaraneus, Early/ Middle Pleistocene, Kozi Grzbiet, I. 2B, buccal view of left a1 (no. MF/1957/17). 


\section{APPENDIX 4}

S. subaraneus Poland. The upper antemolar A5 is usually smaller than A4, however one A5 from Obłazowa 2 Cave is larger than A4 (Harrison 1996). The P4 is characterized by a large parastyle separated from the paracone by a more or less horizontal and rather long parastylar crest. If the P4 is not used a small cingular cusp between the parastyle and protocone is visible. In some specimens, it is even prominent.

Recent $S$. araneus, Poland. The I1 is not fissident. Its upper buccal margin is straight or slightly convex and the apex is turned downwards. The posterior buccal margin can be either undulate or slightly concave and provided with a rather broad cingulum along most of its length. The talon is well developed and buccaly inflated. The apex and the talon are placed at a sharp angle.

Five upper antemolars are present. They are unicuspid and as a rule they diminish in size from A1 to $A 5$ although the largest $A 1$ and $A 2$ are of nearly the same size, A3 and A4 are smaller but also similar in size. The last antemolar A5 is the smallest and always wider than long. When seen from the buccal side it is slightly hidden behind the parastyle of P4.

Two crests run from the antemolar tips - one to the lingual edge and the second to the posterobuccal corner of each of the five teeth. The antero-buccal sides of these teeth are convex and the postero-lingual sides are concave, but in A1-A4 (rarely in A5) these concavities are divided by the lingual crests. The postero-lingual concavities (depressions) are longer and deeper than the antero-lingual ones. The cingula are wide and well developed.

The P4 has a well individualized conical parastyle. It is connected to the paracone by a more or less elongated parastylar crest. The paracone is high and not very inflated, the protocone is well developed and isolated from the small cingular cusp, hypocone, by a wide and deep valley. The hypoconal flange is large and rounded. The cingulum surrounds the parastyle and continues as far as the postero-buccal corner of the tooth. It is only lacking on the buccal side and below the protocone. In unworn teeth, a small cingular cusp is present between the parastyle and the protocone. The posterior emargination is well developed.

The $\mathrm{M} 1$ is roughly square and $\mathrm{M} 2$ rectangular in occlusal view. The parastyles are absent. The hypocones are weakly developed as cuspules on the cingulum which surrounds the hypoconal flanges. They are separated from the protocones by wide valleys. The metalophs are present but they are not very high. Fragments of cingulum are visible on the buccal sides as well as in the protocone/hypocone valleys and the posterior sides of the first and second molars. The hypoconal flanges and emargination are similar to those of P4. The M3 is not very long in its lingual side. Its protocone is well developed and the hypocone is absent.

Fossil S. araneus, Poland. Unfortunately, the number of upper jaw fragments and upper teeth of fossil S. araneus is limited. However, their individual variation is similar to that of the recent form. For example, the parastylar crest of the upper P4 is shorter or longer and situated more or less horizontally, the small cingular cusp situated between the parastyle and the protocone can be more or less distinct, and the shape of the M2 in occlusal view more rectangular or more squared. 